\title{
A study of 15-year aerosol optical thickness and direct shortwave aerosol radiative effect trends using MODIS, MISR, CALIOP and CERES
}

\author{
Ricardo Alfaro-Contreras ${ }^{1}$, Jianglong Zhang ${ }^{1}$, Jeffrey S. Reid ${ }^{2}$, and Sundar Christopher $^{3}$ \\ ${ }^{1}$ Department of Atmospheric Sciences, University of North Dakota, Grand Forks, ND, USA \\ ${ }^{2}$ Marine Meteorology Division, Naval Research Laboratory, Monterey, CA, USA \\ ${ }^{3}$ Department of Atmospheric Science, The University of Alabama in Huntsville, Huntsville, AL, USA \\ Correspondence to: Jianglong Zhang (jzhang@atmos.und.edu)
}

Received: 21 April 2017 - Discussion started: 27 April 2017

Revised: 24 August 2017 - Accepted: 28 August 2017 - Published: 21 November 2017

\begin{abstract}
By combining Collection 6 Moderate Resolution and Imaging Spectroradiometer (MODIS) and Version 22 Multi-angle Imaging Spectroradiometer (MISR) aerosol products with Cloud and Earth's Radiant Energy System (CERES) flux products, the aerosol optical thickness (AOT, at $0.55 \mu \mathrm{m}$ ) and shortwave (SW) aerosol radiative effect (SWARE) trends are studied over ocean for the near-full Terra (2000-2015) and Aqua (2002-2015) data records. Despite differences in sampling methods, regional SWARE and AOT trends are highly correlated with one another. Over global oceans, weak SWARE (cloud-free SW flux) and AOT trends of $0.5-0.6 \mathrm{~W} \mathrm{~m}^{-2}\left(-0.5\right.$ to $\left.-0.6 \mathrm{~W} \mathrm{~m}^{-2}\right)$ and 0.002 AOT decade ${ }^{-1}$ are found using Terra data. Near-zero AOT and SWARE trends are also found for using Aqua data, regardless of the angular distribution models (ADMs) used. Regionally, positive AOT and cloud-free SW flux (negative SWARE) trends are found over the Bay of Bengal, the Arabian Sea, the Arabian/Persian Gulf and the Red Sea, while statistically significant negative trends are derived over the Mediterranean Sea and the eastern US coast. In addition, the global mean instantaneous SW aerosol direct forcing efficiencies are found to be $\sim-60 \mathrm{~W} \mathrm{~m}^{-2} \mathrm{AOT}^{-1}$, with corresponding SWARE values of $\sim-7 \mathrm{~W} \mathrm{~m}^{-2}$ from both Aqua and Terra data, again regardless of CERES ADMs used. Regionally, SW aerosol direct forcing efficiency values of $\sim-40 \mathrm{~W} \mathrm{~m}^{-2} \mathrm{AOT}^{-1}$ are found over the southwest coast of Africa where smoke aerosol particles dominate in summer. Larger (in magnitude) SW aerosol direct forcing efficiency values of -50 to $-80 \mathrm{Wm}^{-2} \mathrm{AOT}^{-1}$ are found over several other dust- and pollutant-aerosol-dominated regions.
\end{abstract}

Lastly, the AOT and SWARE trends from this study are also intercompared with aerosol trends (such as active-based ones) from several previous studies. Findings suggest that a cohesive understanding of the changing aerosol skies can be achieved through the analysis of observations from both passive- and active-based analyses, as well as from both narrowband and broadband datasets.

\section{Introduction}

The significance of aerosol particles for global and regional climate variations has been extensively studied for the past two decades with both observation- and model-based approaches (IPCC, 2013). In particular, studies have suggested that the direct shortwave (SW) aerosol radiative effect (SWARE), which refers to the impacts of aerosol particles on Earth's radiation balance through the absorption and scattering of incoming SW solar energy, can be estimated with the combined use of broadband and narrowband observations on the shortwave spectrum (e.g., Zhang et al., 2005a, b; Loeb and Kato, 2002). For example, using 10 months of collocated Terra Moderate Resolution Imaging Spectroradiometer (MODIS) and Cloud and Earth's Radiant Energy System (CERES) data, Zhang et al. (2005b) derived the spatial distribution of SWARE over global oceans. In that study, the perturbations in top-of-atmosphere (TOA) SW energy due to aerosol particles are estimated using Terra CERES observations. The Terra CERES observations have a large footprint of $\sim 20 \mathrm{~km}$ at nadir (Wielicki et al., 1996). Thus, col- 
located finer-resolution Terra MODIS observations are used for cloud clearing and reporting finer-scale aerosol optical properties within the CERES fields of view (Christopher and Zhang, 2002b; Zhang et al., 2005a, b).

The Terra MODIS, CERES and Multi-angle Imaging Spectroradiometer (MISR; Kahn et al., 2010) instruments have been continuously observing Earth's atmosphere for more than 16 years (2000-2016). Similarly, the MODIS and CERES instruments on board the Aqua satellite have also been in operation for 14 years (2002-2016). Taking advantage of these longer-term datasets from the Aqua and Terra satellites, several studies have already examined temporal variations in aerosol optical thickness (AOT) both on regional and global scales (e.g., Zhang and Reid, 2010; Hsu et al., 2012; Li et al., 2014; Alfaro-Contreras, 2016; Toth et al., 2016). For example, using 10 years (2000-2009) of Collection 5 (C5) Terra and Aqua MODIS Dark Target (DT) AOT data, Zhang and Reid, (2010) found a negligible AOT trend over global oceans but documented three regions with statistically significant increases in aerosol loadings, including the Indian Bay of Bengal, the Arabian Sea and the eastern coast of China. Several other studies have also investigated AOT trends using ground-based Aerosol Robotic NETwork (AERONET) data (Li et al., 2014), spaceborne lidar observations (Toth et al., 2016), and other passive-based observations or model simulations (Thomas et al., 2010; Mishchenko et al., 2012; Hsu et al., 2012; Zhao et al., 2013; Chin et al., 2014).

Nevertheless, to our knowledge, SWARE trends have not been studied with the use of both Terra and Aqua datasets. In addition, the new Collection 6 (C6) MODIS aerosol products have changed the magnitudes of global AOT fields significantly (Levy et al., 2013). Thus, in this study, using C6 MODIS and MISR aerosol products, as well as CERES data, we studied AOT and SWARE trends over global oceans with the goal of exploring the following scientific questions.

1. To what extent have AOT trends changed with the update from MODIS C5 to C6?

2. What are the regional and global AOT trends over global oceans with the use of the near-full Terra/Aqua MODIS and Terra MISR data records?

3. What are the regional and global trends in MODIS and CERES-based SWARE (note that although MODIS data are used for cloud clearing, CERES-inferred SWAREs are independent of forward calculations of MODIS and MISR)?

4. What are the instantaneous SW aerosol direct forcing efficiencies and SWARE values on both regional and global scales using the near-full Aqua and Terra data records?
5. Can cohesive conclusions (trend patterns) be achieved among passive- and active-based AOT as well as SWARE trend analyses?

This paper is organized as follows. Data used in this study are described in Sect. 2. In Sect. 3, differences in AOT trends using C5 and C6 MODIS DT aerosol products are examined for the study period of 2000-2009, and then AOT trends are further derived with the use of near-full Terra MODIS and MISR (2000-2015) as well as Aqua MODIS (2002-2015) data records. In Sect. 4, regional and global SW aerosol direct forcing efficiencies, magnitudes of SWAREs, as well as trends in SWARE are studied using collocated CERES and C6 MODIS DT aerosol products over global oceans. An uncertainty analysis in the derived SWARE trends is also carried out in Sect. 4. In Sect. 5, regionally based AOT and SWARE trends derived from this study are intercompared with aerosol trend analyses estimated from several other studies that use the Cloud-Aerosol Lidar with Orthogonal Polarization (CALIOP), MODIS and MISR instruments. Conclusions and discussions are provided in Sect. 6.

\section{Datasets}

Eight satellite datasets are included in this study (also shown in Table 1). Regional and global over-ocean AOTs were extracted from C6 Terra (MOD04_L2, 2000-2015), Aqua (MYD04_L2, 2002-2015) MODIS DT Level 2 aerosol products (Levy et al., 2013) and Version 22 MISR (2000-2015; Kahn et al., 2010) aerosol products. The Edition 3 Terra and Aqua CERES Earth Radiation Budget Experiment (ERBE)like (ES-8; Barkstrom and Wielicki, 1996) and the Edition 3A CERES single satellite footprint (SSF; Loeb et al., 2003) Level 2 swath products provide instantaneous broadband SW fluxes. CALIOP Level 2, $5 \mathrm{~km}$ cloud layer products (Winker et al., 2010) are also used to assist the cirrus-cloud-related analysis.

\subsection{MODIS DT aerosol products}

The over-ocean C6 MODIS DT aerosol products provide spectral AOT at seven wavelengths ranging from visible to shortwave infrared at a $10 \mathrm{~km}$ nadir spatial resolution, with an increased pixel size of $20 \times 48 \mathrm{~km}$ near the edge of the swath (Levy et al., 2013). Only the $550 \mathrm{~nm}$ AOT products are used in this study. Compared to the over-ocean C5 MODIS DT products, aside from changes in upstream products such as L1B reflectance, land/sea mask and cloud mask, one major change included in the over-ocean C6 MODIS DT data is the use of non-static near-surface wind speeds in the retrieval process (Levy et al., 2013). In this study, only AOT retrievals with a quality assurance (QA) flag of marginal confidence or higher are used. The reported uncertainty in AOT data is on the order of $(-0.02-10 \%),(+0.04+10 \%)($ e.g., Levy et al., 2013), although several studies suggest that higher un- 
Table 1. List of datasets used in the study.

\begin{tabular}{lll}
\hline Datasets & Study periods & Purposes \\
\hline C6 Aqua MODIS DT & Jul 2002-Dec 2015 & AOT trend, cloud fraction \\
C6 Terra MODIS DT & Mar 2000-Dec 2015 & AOT trend, cloud fraction \\
Terra MISR & Mar 2000-Dec 2015 & AOT trend \\
Aqua CERES ES-8/SSF & Jul 2002-Dec 2015 & Cloud-free SW flux trend \\
Terra CERES ES-8/SSF & Mar 2000-Dec 2015 & Cloud-free SW flux trend \\
CALIOP & Jun 2006-Nov 2015 & Thin cirrus cloud mask \\
\hline
\end{tabular}

certainties could be found for individual retrievals (e.g., Shi et al., 2011).

\subsection{MISR aerosol products}

On board the Terra satellite platform, the MISR instrument provides observations at nine different viewing zenith angles $\left(\mathrm{VZA}=0\right.$ (nadir), $\left.\pm 26.1, \pm 45.6, \pm 60.0, \pm 70.5^{\circ}\right)$ at four different spectral bands ranging from 446 to $866 \mathrm{~nm}$, although like MODIS, we focus on the green wavelength here $(558 \mathrm{~nm})$. Even though MISR has a much narrower swath of $\sim 360 \mathrm{~km}$ in comparison to MODIS (Diner et al., 1998), the multi-angle observations from MISR enable a more reliable AOT retrieval over bright scenes such as desert regions (Kahn et al., 2010). Thus, unlike the MODIS and CERESbased analyses in this study, which focus on global oceans, trend analyses from MISR include both land and ocean regions, unless otherwise stated.

\subsection{CERES SSF products and issues}

The CERES SSF data are constructed through weighted averaging of MODIS aerosol and cloud retrievals within a CERES footprint based on CERES point spread function (PSF; Loeb et al., 2003). The CERES instrument measures TOA broadband radiance. To convert from radiance to flux, angular distribution models (ADMs) are needed (e.g., Loeb et al., 2003). For the CERES SSF products, CERES ADMs (Loeb et al., 2003) are used to convert CERES radiance to flux. Over cloud-free oceans, AOT is accounted for in CERES ADMs through the use of the radiative transfer modeled anisotropic factors, stratified as sea salt AOT values (Loeb et al., 2003), without considering the impacts of absorbing aerosols. The CERES SSF data cannot be directly used in this study, however, simply because they are constructed with the MODIS products in active production at the time of data collection. That is, both Collection 4 (C4; before 2006) and C5 (after 2006) MODIS DT aerosol data were used in constructing CERES SSF data (http://ceres. larc.nasa.gov/products.php?product=SSF-Level2). This creates a problem for using CERES SSF in trend analysis, as changes are expected in both global and regional estimations of AOTs between C4 and C5 MODIS DT aerosol products. In addition, C6 MODIS aerosol data, which are currently avail- able, are not included in the CERES SSF data for the study period. Thus, the CERES SSF data are used in this study by collocating with CERES ES-8 and C6 MODIS DT data, which are explained in detail later.

\subsection{CERES ES-8 products}

The CERES ES-8 data are also available for the near-full Terra and Aqua data records. The CERES ES- 8 data are constructed by using ADMs from the ERBE-like algorithm (Suttles et al., 1988). No aerosol properties are considered in constructing ERBE ADMs. Thus, CERES ES- 8 data are used for evaluating the impact of ADMs on CERES-derived SWAREs and for intercomparison with CERES-SSF-based analyses in this study.

\subsection{Collocated CERES SSF, ES-8 and MODIS DT products}

CERES SSF, CERES ES-8 and C6 MODIS DT datasets were collocated in this study using 14 years of Aqua and 16 years of Terra data. This is achieved by collocating CERES SSF and ES-8 data as the first step. Note that CERES SSF data include geo-locations at the surface, but CERES ES-8 data report geo-locations at TOA; thus, the collocation is performed by selecting pairs of pixel-level data points from both products that are in the vicinity of each other (within $2^{\circ}$ latitude/longitude) and have identical raw observations (CERES upward "TOT-filtered radiance" and "SW-filtered radiance"). Also, CERES-SSF-reported "Clear-area percent coverage at subpixel resolution" values, which are used to define the clear-area percentage (CP) in this study, are applied as the initial cloud screen method. Only collocated CERES SSFES-8 pairs that have CP values of $95 \%$ or higher are included in further analyses. Note that only CERES pixels that have a MODIS reported cloud fraction of $1 \%$ or less are used in the final process. A more relaxed CP threshold of $95 \%$ is adopted here, partially for studying the impact of cloud contamination on CERES-derived SWAREs as shown in Table 5.

As the second step, the collocated CERES SSF and ES8 data are further collocated with C6 MODIS DT data. Only MODIS and CERES data that are from the same satellite platform are used in the collocation. To collocate MODIS and CERES data, surface geo-locations (lati- 
tudes/longitudes) of both datasets are first identified and the two datasets are collocated in space and time based on the PSF of the CERES instrument (Wielicki et al., 1996; Christopher and Zhang, 2002a; b, Zhang and Christopher, 2003). Arithmetic averages are performed for MODIS data points that are within a CERES footprint.

CERES data are available from three scan modes: the cross-track, rotating azimuth plane scan and fixed azimuth plane scan modes. To maintain data consistency, only crosstrack mode CERES data from Terra and Aqua are used in this study. Also, to further screen potential noisy data, only CERES observations with valid SW flux retrievals (from CERES ES-8 or CERES SSF) and a VZA as well as a solar zenith angle (SZA) less than $60^{\circ}$ are considered in this study. Over-land observations are further excluded in the study by only using collocated pairs that have the CERES ES-8 scene IDs of "Clear Ocean", "Partly Cloudy Over Ocean" and "Mostly Cloudy Over Ocean". Cloud and aerosol properties within a CERES observation are reported based on the collocated C6 MODIS DT products. The following ancillary data are also recorded for each CERES observation: the total number of collocated C6 MODIS DT retrievals, the number of valid C6 MODIS DT retrievals (with valid cloud fraction and AOT values), and the number of valid C6 MODIS DT retrievals with QA flags of "marginal", "good" and "very good". Lastly, only CERES pixels with a CP larger than $99 \%$ and a reported MODIS cloud fraction (CF) of less than $1 \%$ and are used in this study and the impacts of cloud contamination on the derived SWARE trends are also evaluated later in this paper.

\subsection{Collocate CERES ES-8/SSF, MODIS DT and CALIOP products}

Using collocated CALIOP and MODIS observations, several studies have suggested that MODIS AOT retrievals may be contaminated with optically thin cirrus clouds (OTCs; e.g., Kaufman et al., 2005; Huang et al., 2011; Feng et al., 2011; Toth et al., 2013). To further study the effects of OTC on the trend analysis, the $5 \mathrm{~km}$ CALIOP cloud layer product (Winker et al., 2010) is utilized. The CALIOP cloud layer (CAL_LID_L2_05kmCLay) data are spatiotemporally collocated with the already collocated MODIS-CERES datasets onboard the Aqua platform. CALIPSO's Feature Classification Flag is used to locate residual OTC within CERES observations. It should be noted that CALIOP's data record spans only about half of our study period (June 2006December 2015) and is available only on the Aqua platform; thus, it will be used as a secondary analysis presented in Sect. 4.2. Note that the CERES CALIPSO CloudSat MODIS (C3M) products, which are constructed by collocating CERES SSF, CALIPSO, CloudSat and MODIS data (Kato et al., 2011), are also available from 2006 to 2011 (https://ceres.larc.nasa.gov/products.php?product= CCCM). However, the C3M data are not available after 2011.
Also, to avoid decoupling the impacts of ADMs and cirrus cloud effects, a simple approach, as mentioned in this section is used in this study.

\section{AOT trends from over-ocean DT MODIS data}

To initiate this study, we begin with an update to global trend analyses in AOT. Included are two components. First, we evaluate whether recent changes in the MODIS aerosol product affect past conclusions on regional aerosol trends over the globe. This is followed by an extension of the trend analysis to the entire 2000-2015 study period (Sect. 3.2).

\subsection{Update of AOT trends from Collection 5 to Collection 6}

In the Zhang and Reid (2010) paper, 10 years of C5 DT MODIS over-ocean data were used in deriving regional and global AOT trends. With the recent release of C6 Aqua and Terra DT MODIS data, including significant updates to calibration and cloud-clearing algorithms, it is worth a short reproduction of this work with current products.

Similar to Zhang and Reid (2010), Level 2 C6 DT over water Terra MODIS data were binned into $1^{\circ} \times 1^{\circ}$ (latitude/longitude) monthly averages. "Bad" retrievals, as indicated by the QA flag included in the dataset, are discarded from the analysis, as are MODIS cloud fraction above $80 \%$, to minimize the effect of cloud contamination (Zhang and Reid, 2010). Using the monthly gridded over-ocean C6 Terra MODIS DT data from 2000 to 2009 (excluding August 2000 and June 2001 as these months contained less than 20 days of valid data), regional AOT trends, as well as trend significances (based on Weatherhead et al., 1998, as suggested from Zhang and Reid, 2010) were derived and are shown in Fig. 1a. Trend significances are computed based on two statistical methods. To be consistent with Zhang and Reid (2010), the Weatherhead method (Weatherhead et al., 1998; hereafter WH), which accounts for data autocorrelation, is used to calculate trend significances for monthly based AOT data. For a comparison purpose, the MannKendall method (e.g., Mann, 1945; Kendall, 1975 - hereafter MK) is also used. Note that the MK method is used as it can be applied to estimate trend significances for seasonally based analysis as discussed in Sect. 4. Both methods are applied in Sects. 3 and 4, wherever applicable.

To create Fig. 1, data are deseasonalized by removing 10year averages from any given month, for each grid point. Also, AOT trends are derived only for bins which have more than 72 months $(60 \%)$ of valid data records. In Fig. 1a, regions with statistically significant trends at a $95 \%$ confidence interval (from WH), are indicated with black dots.

To intercompare AOT trend analyses from Zhang and Reid (2010), AOT trends from 10 selected regions are computed as shown in Table 2. Also, as suggested by Zhang and Reid 


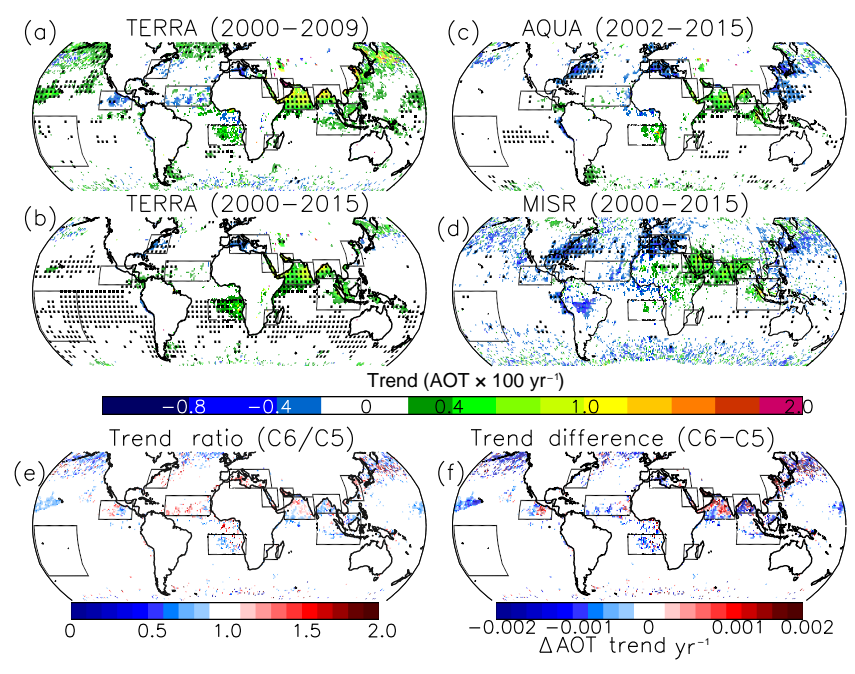

Figure 1. Spatial distribution of trends for (a) over-ocean Terra MODIS DT AOT for 2000-2009, (b) over-ocean Terra MODIS DT AOT for 2000-2015, (c) over-ocean Aqua MODIS DT AOT for 2002-2015, and (d) over-land and ocean Terra MISR AOT for 2000-2015 for every $1^{\circ} \times 1^{\circ}$ bin. (e) Ratios of MODIS C6 to C5 AOT trends for the study period of 2000-2009 and (f) differences in MODIS C6 to C5 AOT trends for the study period of 2000-2009. Regions with statistically significant trends at a confidence interval of $95 \%$ are indicated with black dots. Panels (e) and (f) are constructed with the use of grids with AOT trends above or below \pm 0.002 AOT year ${ }^{-1}$. Also, the leftmost (rightmost) segments of the color bars in panels (e) and (f) represent data points equal to or less (greater) than the values labeled.

(2010), the AOT trend from the remote ocean (RO; $40^{\circ} \mathrm{S}-$ $0^{\circ}, 179-140^{\circ} \mathrm{W}$ ) is used as a proxy for unrealized bias in the AOT trend due to issues such as calibration and signal drifts, as this is the region that is least affected by any major aerosol plumes originating from the main continents. The ratios and differences in AOT trends for both C6 and C5 Terra MODISbased analysis are also shown in Fig. 1e and f, respectively, for the study period of 2000-2009. Only grids with AOT trends above or below \pm 0.002 AOT year ${ }^{-1}$ are used in this comparison.

As suggested from Table 2, both AOT trends and trend significances (based on $\mathrm{WH}$ ) are similar with the use of $\mathrm{C} 5$ and C6 Terra MODIS DT over-ocean data for the study period of 2000-2009. This suggests that although documentable changes are made to the C6 MODIS DT over-ocean data (Levy et al., 2013), the impact of those changes on global and regional AOT trend analyses is rather marginal. For comparison purposes, Table 2 also includes trend significances derived using the Mann-Kendall method $(|z|)$ for the C6 MODIS DT-based analysis, and consistent results are found from both methods a majority of the time.

Lastly, regional and global averages of over-ocean C5 and C6 Terra MODIS DT AOTs are also shown in Table 2 for the period of 2000-2009. Note that in Zhang and Reid (2010), data-assimilation quality C5 MODIS DT data, which are implemented with extensive QA steps (e.g., Zhang and Reid, 2006; Shi et al., 2011), were used. Here, regional and global mean C5 AOTs are derived using similar steps as were used in constructing the C6 AOT data, which are different from the data-assimilation quality C5 MODIS DT data as used in Zhang and Reid (2010). Nevertheless, as suggested from Zhang and Reid (2010), although QA steps could lower the mean global over-ocean AOTs from $\sim 0.15$ to $\sim 0.11$, in part due to the removal of cloud-contaminated retrievals, minor impacts on the AOT trend analysis are reported. As suggested from Table 2, a $10 \%$ reduction in global mean over-ocean AOT is found for the C6 MODIS DT data compared to the C5 data, possibly due to a reduction in marine background AOTs (e.g., the enhanced southern ocean anomaly feature, as shown in Toth et al., 2013, no longer exists in the C6 product).

\subsection{AOT trends from near-full Terra and Aqua data records}

Extending the analysis from the previous section, AOT trends are evaluated for the near-full available data record (March 2000-December 2015 for MODIS Terra and MISR and July 2002-December 2015 for MODIS Aqua) of C6 over-ocean MODIS DT and MISR aerosol products. The C6 MODIS DT data are processed and filtered with the same steps as mentioned in Sect. 3.1 to construct $1^{\circ} \times 1^{\circ}$ (latitude/longitude) monthly averages for trend estimates. MISR products are also binned into monthly averaged $1^{\circ} \times 1^{\circ}$ degree bins and filtered according to Zhang et al. (2017).

Figure 2 depicts the C6 MODIS Terra (Fig. 2a), C6 MODIS Aqua (Fig. 2b) and v22 MISR (Fig. 2c)-based global aerosol distributions (latitude -60 to $60^{\circ}$ ) using monthly gridded AOTs. Only those bins with more than 1000 data counts were considered for this analysis. This is an arbitrary threshold selected for removing some over-land water retrievals over scenes such as lakes. It is also partially used for ensuring sufficient data are included in the trend analysis. Figure $2 \mathrm{a}$ and $\mathrm{b}$ show a high level of similarity over most of the globe, which is consistent with what has been reported by Remer et al. (2006) using 3 years of C5 MODIS data. Similar spatial patterns are also found for MODIS- and MISR-based AOT analyses over global oceans (Fig. 2c). This is further confirmed by Fig. $2 \mathrm{~d}$ and e, which show the differences and the ratios between Terra MODIS and Terra MISR AOTs. Nevertheless, the band of high AOT over the southern oceans, which is identified as a potential artifact in both C5 MODIS and MISR aerosol products that may be due to cloud contamination (Toth et al., 2013), is no longer apparent in the C6 MODIS DT aerosol products.

Using data shown in Fig. 2, the time series of over-ocean global mean AOT are also examined and shown in Fig. 3. Figure 3a shows the monthly averaged C6 MODIS Aqua (red), MODIS Terra (blue) and MISR (green) AOTs over 
Table 2. AOT trend analyses for global and selected regions as suggested from Zhang and Reid (2010). Both trends from Collection 5 (C5, Zhang and Reid, 2010) and Collection 6 (C6) over-water Terra MODIS AOT data are shown for the study period of 2000-2009. The trend significances are derived using two different methods $\left(\left|\omega / \sigma_{\omega}\right|\right.$ and $|z|$ values as estimated with the Weatherhead and Mann-Kendall methods, respectively). The corrected slopes refer to the slopes after accounting for the changes over the remote-ocean region. AOT trends and trend significances for C5 MODIS DT data are obtained from Zhang and Reid, (2010), which are derived using data-assimilation quality C5 MODIS DT data. For illustration purposes, C5* and C6 Terra MODIS AOT values, derived using similar methods as mentioned in this study, are also listed. C5* MODIS DT AOTs listed here are not from the same data-assimilation quality products as used in Zhang and Reid (2010). NW coast, SW coast, SE coast and E coast refer to the northwest coast, southwest coast, southeast coast and east coast, respectively. Note that, in this paper, SW means "southwest" when referring to a geographical area and "shortwave" when referring to flux.

\begin{tabular}{|c|c|c|c|c|c|c|c|c|c|c|c|}
\hline \multirow[t]{2}{*}{ Region } & \multirow[t]{2}{*}{ Latitude } & \multirow[t]{2}{*}{ Longitude } & \multicolumn{2}{|c|}{$\begin{array}{l}\text { Slope AOT decade } \\
\text { Terra }\end{array}$} & \multicolumn{3}{|c|}{$\begin{array}{l}\text { Trend significance } \\
\text { (Terra) }\end{array}$} & \multicolumn{2}{|c|}{$\begin{array}{l}\text { Corrected slope } \\
\text { AOT decade }^{-1} \text { (Terra) }\end{array}$} & \multicolumn{2}{|c|}{$\begin{array}{l}\text { Mean AOT } \\
\text { (Terra) }\end{array}$} \\
\hline & & & $\mathrm{C} 5$ & C6 & $\mathrm{C} 5\left|\omega / \sigma_{\omega}\right|$ & $\mathrm{C} 6\left|\omega / \sigma_{\omega}\right|$ & $\mathrm{C6}|Z|$ & $\mathrm{C} 5$ & C6 & $\mathrm{C} 5^{*}$ & C6 \\
\hline Global & & & 0.010 & 0.011 & 3.60 & 4.85 & 6.88 & 0.003 & 0.005 & 0.154 & 0.140 \\
\hline Africa (NW coast) & $8-24^{\circ} \mathrm{N}$ & $60-18^{\circ} \mathrm{W}$ & -0.006 & -0.004 & 0.61 & 0.37 & 0.18 & -0.013 & -0.010 & 0.247 & 0.257 \\
\hline Bay of Bengal & $10-25^{\circ} \mathrm{N}$ & $78-103^{\circ} \mathrm{E}$ & 0.076 & 0.074 & 5.63 & 4.79 & 4.71 & 0.069 & 0.068 & 0.319 & 0.326 \\
\hline Coastal China & $20-40^{\circ} \mathrm{N}$ & $110-125^{\circ} \mathrm{E}$ & 0.069 & 0.086 & 4.06 & 4.69 & 4.78 & 0.062 & 0.080 & 0.460 & 0.462 \\
\hline Central America & $5-20^{\circ} \mathrm{N}$ & $120-90^{\circ} \mathrm{W}$ & -0.016 & -0.011 & 1.73 & 1.12 & 0.57 & -0.023 & -0.017 & 0.151 & 0.165 \\
\hline Arabian Sea & $5-23^{\circ} \mathrm{N}$ & $50-78^{\circ} \mathrm{E}$ & 0.065 & 0.077 & 5.40 & 4.95 & 4.03 & 0.058 & 0.071 & 0.319 & 0.329 \\
\hline Mediterranean Sea & $30-45^{\circ} \mathrm{N}$ & $0-40^{\circ} \mathrm{E}$ & -0.009 & -0.009 & 0.94 & 0.96 & 1.25 & -0.016 & -0.015 & 0.200 & 0.210 \\
\hline Africa (SW coast) & $23-7^{\circ} \mathrm{S}$ & $20^{\circ} \mathrm{W}-15^{\circ} \mathrm{E}$ & 0.016 & 0.018 & 1.35 & 1.52 & 1.46 & 0.009 & 0.012 & 0.179 & 0.188 \\
\hline North America (E coast) & $30-45^{\circ} \mathrm{N}$ & $80-60^{\circ} \mathrm{W}$ & -0.008 & -0.010 & 1.07 & 1.50 & 1.04 & -0.015 & -0.016 & 0.157 & 0.160 \\
\hline Africa (SE coast) & $27-15^{\circ} \mathrm{S}$ & $32-45^{\circ} \mathrm{E}$ & 0.017 & 0.015 & 2.12 & 1.93 & 3.06 & 0.010 & 0.009 & 0.129 & 0.158 \\
\hline Southeast Asia & $15^{\circ} \mathrm{S}-10^{\circ} \mathrm{N}$ & $80-120^{\circ} \mathrm{E}$ & 0.014 & 0.016 & 0.80 & 0.86 & 4.89 & 0.007 & 0.010 & 0.176 & 0.184 \\
\hline Remote ocean & $40^{\circ} \mathrm{S}-0^{\circ}$ & $179-140^{\circ} \mathrm{W}$ & 0.007 & 0.006 & N/A & 2.32 & 2.93 & 0 & 0 & 0.100 & 0.107 \\
\hline
\end{tabular}

global oceans for the entire time frame of each dataset. It should be noted that over-land observations from MISR are not included in global averages in order to get a more direct comparison with the over-ocean MODIS DT aerosol datasets. Monthly variations in globally averaged (simple arithmetic mean) AOTs can be observed, with the solid lines showing the AOT trends for the entire time period for each sensor. Similar to Zhang and Reid (2010), the lowest monthly averaged MODIS AOTs are found during the northern hemispheric winter months, while the highest aerosol loading activities over global oceans seem to occur during the northern hemispheric spring and summer months.

Figure $3 b$ shows AOT anomalies after deseasonalizing the monthly data shown in Fig. 3a. Terra MODIS and MISR show trends of differing signs; a statistically significant increase/decrease in monthly-mean AOT values of $0.008 /-0.005$ AOT decade ${ }^{-1}$ is found when using Terra MODIS/MISR data for the study period of 2000-2015. In comparison, a statistically insignificant global over-ocean AOT trend is found to be 0.0003 AOT decade ${ }^{-1}$ using Aqua MODIS data for the study period of 2002-2015. A trend difference is clearly seen even if we restrict all datasets to the same study period of 2002-2015, which could be an indication of potential calibration-related issues with one or all of the sensors.

Zhang and Reid (2010) suggested that since the remoteocean region (defined in Table 2) is least affected by major aerosol plumes of continental origin, the AOT trend from this region may be used for checking calibration-related issues or some other unrealized uncertainties originating from the upstream data used. A caveat here is that we assume that the calibration degradation propagates linearly into AOT. The correction might therefore be an under- or overcorrection in those higher-AOT areas. Similar to Fig. 3b, Fig. 3c depicts the monthly averaged deseasonalized AOTs over the remoteocean region where the monthly anomalies and trend lines are visible. Similar to Zhang et al. (2017), an insignificant trend of 0.0003 AOT decade ${ }^{-1}$ is found for the remote-ocean region using Aqua MODIS data, while a statistically significant (WH method) trend of $0.006 /-0.004$ AOT decade $^{-1}$ is found for the same region with the use of deseasonalized Terra MODIS/MISR data. Those differences in AOT trends are not surprising. For example, a recent study suggests potential cross-talk among Terra MODIS thermal channels, which will affect MODIS cloud detection (Moeller and Frey, 2016) and, correspondingly, Terra MODIS AOT trends. Similarly, Limbacher and Kahn (2017) reported an up to $2 \%$ decrease in MISR signals from 2002 to 2014 that could affect MISR AOT trends. AOT trends estimated from this study are henceforth adjusted based on AOT trends detected from the remote-ocean region; this is done to reduce potential impacts from upstream data used in the AOT retrievals by assuming that a near-zero AOT trend should be observed over the remote-ocean region (shown in Table 3).

Using monthly gridded data, AOT grid-level trends are also estimated on a global scale, for MODIS Terra- (Fig. 1b), MODIS Aqua- (Fig. 1c) and MISR (Fig. 1d)-based analysis for the entire data record period. Again, the black-dotted areas on the map are for regions with statistically significant trends at a $95 \%$ confident interval estimated using the WH method. When comparing them with the 10-year analysis as mentioned in Sect. 3.1 (Fig. 1a), some similarities are 
Table 3. Multiyear AOT and cloud-free flux trends (2002-2015 for MODIS Aqua; 2000-2015 for MODIS Terra; and 2000-2015 for MISR) for global and selected regions. AOT trends are calculated using monthly averaged, deseasonalized AOTs derived from the MODIS Collection 6 and MISR aerosol products. Cloud-free flux trends are calculated using seasonally averaged, deseasonalized cloud-free fluxes derived using the collocated MODIS-CERES SSF/ES-8 dataset. Various filtering criteria are applied to the data and described in the text. Trends that are statistically significant with a confidence interval of $95 \%$ (utilizing the Weatherhead method for monthly averages and the Mann-Kendall method for seasonal averages) are highlighted in bold.

\begin{tabular}{|c|c|c|c|c|c|c|c|c|c|c|c|c|}
\hline \multirow[t]{2}{*}{ Regional } & \multirow[t]{2}{*}{ Latitude } & \multirow[t]{2}{*}{ Longitude } & \multicolumn{3}{|c|}{ AOT decade ${ }^{-1}$} & \multicolumn{3}{|c|}{ Corrected AOT decade ${ }^{-1}$} & \multicolumn{2}{|c|}{$\begin{array}{l}\text { Cloud-free flux } \\
\mathrm{W} \mathrm{m}^{-2} \text { decade }^{-1}\end{array}$} & \multicolumn{2}{|c|}{$\begin{array}{l}\text { Corrected Cloud- } \\
\text { free flux } \\
\mathrm{W} \mathrm{m}^{-2} \text { decade }^{-1}\end{array}$} \\
\hline & & & $\begin{array}{r}\text { MODIS } \\
\text { Aqua }\end{array}$ & $\begin{array}{r}\text { MODIS } \\
\text { Terra }\end{array}$ & MISR & $\begin{array}{r}\text { MODIS } \\
\text { Aqua }\end{array}$ & $\begin{array}{r}\text { MODIS } \\
\text { Terra }\end{array}$ & MISR & $\begin{array}{l}\text { Aqua } \\
\text { ES-8 } \\
\text { SSF }\end{array}$ & $\begin{array}{l}\text { Terra } \\
\text { ES-8 } \\
\text { SSF }\end{array}$ & $\begin{array}{l}\text { Aqua } \\
\text { ES-8 } \\
\text { SSF }\end{array}$ & $\begin{array}{l}\text { Terra } \\
\text { ES-8 } \\
\text { SSF }\end{array}$ \\
\hline Global & & & 0.0003 & 0.008 & -0.005 & $\sim 0$ & 0.002 & -0.001 & $\begin{array}{l}-0.50 \\
-0.26\end{array}$ & $\begin{array}{l}-1.50 \\
-1.22\end{array}$ & $\begin{array}{l}0 \\
-0.01\end{array}$ & $\begin{array}{l}-0.58 \\
-0.52\end{array}$ \\
\hline $\begin{array}{l}\text { Africa } \\
\text { (NW coast) }\end{array}$ & $8-24^{\circ} \mathrm{N}$ & $60-18^{\circ} \mathrm{W}$ & 0.002 & 0.009 & -0.008 & 0.002 & 0.003 & -0.004 & $\begin{array}{l}0.56 \\
0.71\end{array}$ & $\begin{array}{l}-1.79 \\
-1.29\end{array}$ & $\begin{array}{l}1.06 \\
0.96\end{array}$ & $\begin{array}{l}-0.87 \\
-0.59\end{array}$ \\
\hline $\begin{array}{l}\text { Bay of Ben- } \\
\text { gal }\end{array}$ & $10-25^{\circ} \mathrm{N}$ & $78^{\circ} \mathrm{E}-103^{\circ} \mathrm{E}$ & 0.031 & 0.056 & 0.018 & 0.031 & 0.050 & 0.022 & $\begin{array}{l}2.28 \\
1.91\end{array}$ & $\begin{array}{l}0.79 \\
0.75\end{array}$ & $\begin{array}{l}2.78 \\
2.16\end{array}$ & $\begin{array}{l}1.71 \\
1.45\end{array}$ \\
\hline $\begin{array}{l}\text { Coastal } \\
\text { China }\end{array}$ & $20-40^{\circ} \mathrm{N}$ & $110-125^{\circ} \mathrm{E}$ & -0.035 & 0.007 & -0.014 & -0.035 & 0.001 & -0.01 & $\begin{array}{l}-0.42 \\
0.04\end{array}$ & $\begin{array}{l}-2.51 \\
-2.09\end{array}$ & $\begin{array}{l}0.08 \\
0.29\end{array}$ & $\begin{array}{l}-1.59 \\
-1.39\end{array}$ \\
\hline $\begin{array}{l}\text { Central } \\
\text { America }\end{array}$ & $5-20^{\circ} \mathrm{N}$ & $120-90^{\circ} \mathrm{W}$ & 0.007 & 0.002 & -0.011 & 0.007 & -0.004 & -0.007 & $\begin{array}{l}-0.45 \\
-0.11\end{array}$ & $\begin{array}{l}-1.85 \\
-1.33\end{array}$ & $\begin{array}{l}0.05 \\
0.14\end{array}$ & $\begin{array}{l}-0.93 \\
-0.63\end{array}$ \\
\hline Arabian Sea & $5-23^{\circ} \mathrm{N}$ & $50-78^{\circ} \mathrm{E}$ & 0.039 & 0.057 & 0.033 & 0.039 & 0.051 & 0.037 & $\begin{array}{l}2.61 \\
2.24\end{array}$ & $\begin{array}{l}0.90 \\
0.94\end{array}$ & $\begin{array}{l}3.11 \\
2.49\end{array}$ & $\begin{array}{l}1.82 \\
1.64\end{array}$ \\
\hline $\begin{array}{l}\text { Mediterranean } \\
\text { Sea }\end{array}$ & $30-45^{\circ} \mathrm{N}$ & $0-40^{\circ} \mathrm{E}$ & -0.025 & -0.014 & -0.029 & -0.025 & -0.020 & -0.025 & $\begin{array}{l}-0.91 \\
-0.72\end{array}$ & $\begin{array}{l}-2.93 \\
-2.46\end{array}$ & $\begin{array}{l}-0.41 \\
-0.47\end{array}$ & $\begin{array}{l}-2.01 \\
-1.76\end{array}$ \\
\hline $\begin{array}{l}\text { Africa } \\
\text { (SW coast) }\end{array}$ & $23-7^{\circ} \mathrm{S}$ & $20^{\circ} \mathrm{W}-15^{\circ} \mathrm{E}$ & 0.016 & 0.025 & 0.002 & 0.016 & 0.019 & 0.006 & $\begin{array}{l}-0.19 \\
0.13\end{array}$ & $\begin{array}{l}-0.85 \\
-0.57\end{array}$ & $\begin{array}{l}0.31 \\
0.38\end{array}$ & $\begin{array}{l}0.07 \\
0.13\end{array}$ \\
\hline $\begin{array}{l}\text { East coast } \\
\text { North Amer- } \\
\text { ica }\end{array}$ & $30-45^{\circ} \mathrm{N}$ & $80-60^{\circ} \mathrm{W}$ & -0.028 & -0.016 & -0.026 & -0.028 & -0.022 & -0.022 & $\begin{array}{l}-2.29 \\
-1.65\end{array}$ & $\begin{array}{l}-3.57 \\
-2.73\end{array}$ & $\begin{array}{l}-1.79 \\
-1.40\end{array}$ & $\begin{array}{l}-2.65 \\
-2.03\end{array}$ \\
\hline $\begin{array}{l}\text { Africa } \\
\text { (SE coast) }\end{array}$ & $27-15^{\circ} \mathrm{S}$ & $32-45^{\circ} \mathrm{E}$ & 0.010 & 0.017 & -0.0001 & 0.010 & 0.011 & 0.004 & $\begin{array}{l}-0.01 \\
-0.25\end{array}$ & $\begin{array}{l}-1.46 \\
-1.27\end{array}$ & $\begin{array}{l}0.49 \\
0\end{array}$ & $\begin{array}{l}-0.54 \\
-0.57\end{array}$ \\
\hline SE Asia & $15^{\circ} \mathrm{S}-10^{\circ} \mathrm{N}$ & $80-120^{\circ} \mathrm{E}$ & 0.013 & 0.020 & 0.004 & 0.013 & 0.014 & 0.008 & $\begin{array}{l}0.02 \\
0.60\end{array}$ & $\begin{array}{l}-1.07 \\
-0.32\end{array}$ & $\begin{array}{l}0.52 \\
0.85\end{array}$ & $\begin{array}{l}-0.15 \\
0.38\end{array}$ \\
\hline $\begin{array}{l}\text { Remote } \\
\text { ocean }\end{array}$ & $40^{\circ} \mathrm{S}-0^{\circ}$ & $179-140^{\circ} \mathrm{W}$ & 0.0003 & 0.006 & -0.004 & 0 & $\mathbf{0}$ & $\mathbf{0}$ & $\begin{array}{l}-\mathbf{0 . 5 0} \\
-0.25\end{array}$ & $\begin{array}{l}-0.92 \\
-0.70\end{array}$ & $\begin{array}{l}\mathbf{0} \\
0\end{array}$ & $\begin{array}{l}\text { 0 } \\
\text { 0 }\end{array}$ \\
\hline Red Sea & $15-30^{\circ} \mathrm{N}$ & $30-45^{\circ} \mathrm{E}$ & 0.081 & 0.100 & 0.041 & 0.081 & 0.094 & 0.045 & $\begin{array}{l}2.52 \\
2.08\end{array}$ & $\begin{array}{l}-0.27 \\
-0.60\end{array}$ & $\begin{array}{l}3.02 \\
2.33\end{array}$ & $\begin{array}{l}0.65 \\
0.1\end{array}$ \\
\hline Persian Gulf & $24-30^{\circ} \mathrm{N}$ & $50-60^{\circ} \mathrm{E}$ & 0.033 & 0.081 & 0.046 & 0.033 & 0.075 & 0.050 & $\begin{array}{l}1.76 \\
1.16\end{array}$ & $\begin{array}{l}-0.64 \\
-0.92\end{array}$ & $\begin{array}{l}2.26 \\
1.41\end{array}$ & $\begin{array}{l}0.28 \\
-0.22\end{array}$ \\
\hline
\end{tabular}

clearly visible. For example, increasing AOT trends are observed over the Arabian Sea and the Indian Bay of Bengal, while decreasing trends are observed over the Mediterranean Sea and the east coast of the US from both Fig. 1a and b. Nevertheless, for some regions, such as over coastal China, Fig. 1a shows a positive AOT trend, but a near-zero AOT trend is found in Fig. 1b. A recent study suggests a possible increase in AOT from 2000-2007 over coastal China, followed by a decreasing trend from 2008-2015 (Zhang et al., 2017), which can be used to explain the differences as observed in Fig. 1 over coastal China. Likewise, regional analyses are also conducted as documented by Table 3 and Fig. 4 . In addition to the regions reported by Zhang and Reid (2010), two regions have been added to the study which include the Persian Gulf $\left(24-30^{\circ} \mathrm{N}, 50-60^{\circ} \mathrm{E}\right)$ and the Red Sea (15$\left.30^{\circ} \mathrm{N}, 30-45^{\circ} \mathrm{E}\right)$. All regions are outlined by black boxes in Fig. 1.
Unlike the insignificant AOT trends on the global scale, both statistically significant positive and negative trends are found for several regions as shown in Fig. 4 (as well as Table 3). For example, statistically significant positive AOT trends (statistically significant trends are denoted by bold font in Table 3) are found from all three datasets (Terra and Aqua MODIS DT and MISR over water aerosol products) over the Bay of Bengal (Fig. 4a), the Arabian Sea (Fig. 4b) and the Red Sea (Fig. 4d). Note that both the Bay of Bengal and the Arabian Sea have been identified in Zhang and Reid (2010) as regions with statistically significant positive trends for the study period of 2000-2009. However, the rates of increase in aerosol loading have plausibly slowed down over the last 5 years for both regions, indicated by $\sim 20-30 \%$ reductions in AOT trends when estimated using the near-full Terra data records. The flattening of AOT trends with respect to time can also be observed in Fig. 4 for both regions for 2010-2015. The Red Sea and the Persian Gulf are newly 

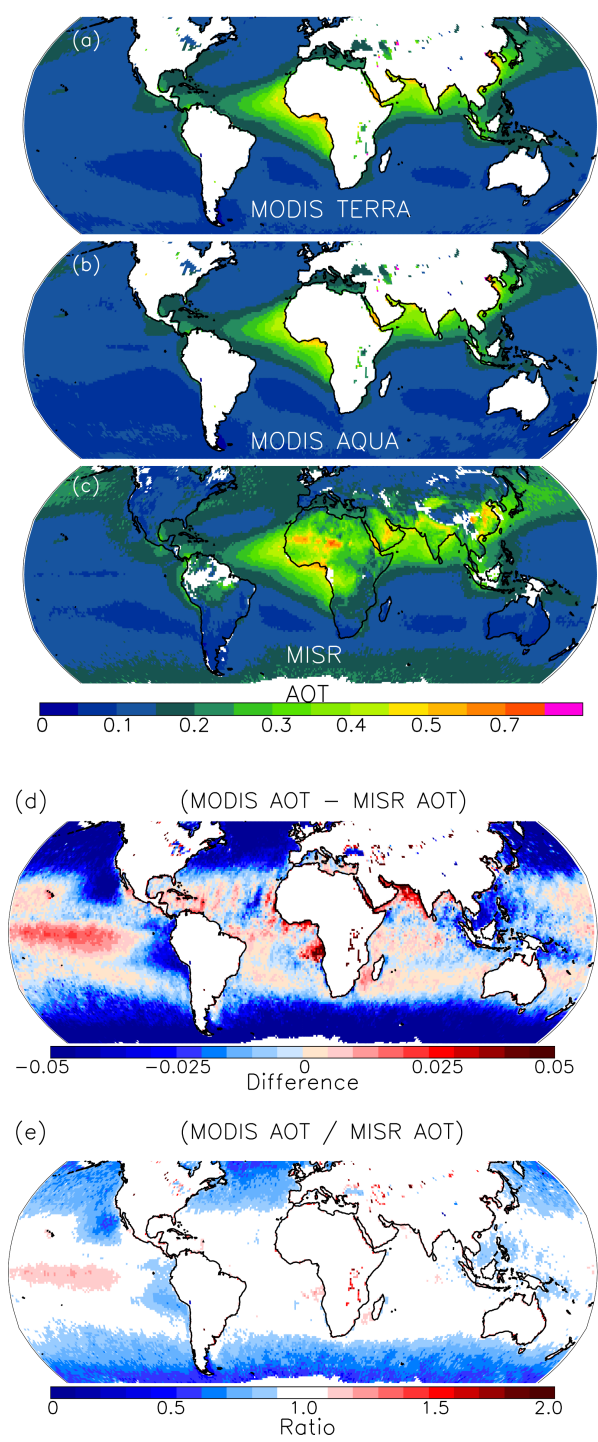

Figure 2. (a) The global distribution of daytime AOTs constructed using 16 years (2000-2015) of monthly averaged over-ocean C6 Terra MODIS AOTs at a $1^{\circ} \times 1^{\circ}$ (latitude/longitude) resolution. Only those bins with more than 1000 data counts were considered for this analysis. (b) Similar to (a), but using over-ocean C6 Aqua MODIS AOTs for the study period of 2002-2015. (c) Similar to (a), but using both over-ocean and over-land Terra MISR AOT data for the study period of 2000-2015. (d) Differences in gridded AOTs between Terra MODIS and Terra MISR. (e) The ratios of gridded AOTs between Terra MODIS and Terra MISR.

introduced for this study but seem to show the highest increase in aerosol loading during the study period (as derived from Terra data). This increase in AOT has been attributed to a number of mechanisms, including a trend in surface wind, precipitation and soil moisture (Al Senafi and Anis, 2015; Klingsmuller et al., 2016), as well as a climatological deepening of the summertime monsoonal low over the Arabian Sea (Solmon et al., 2015). Statistically significant negative

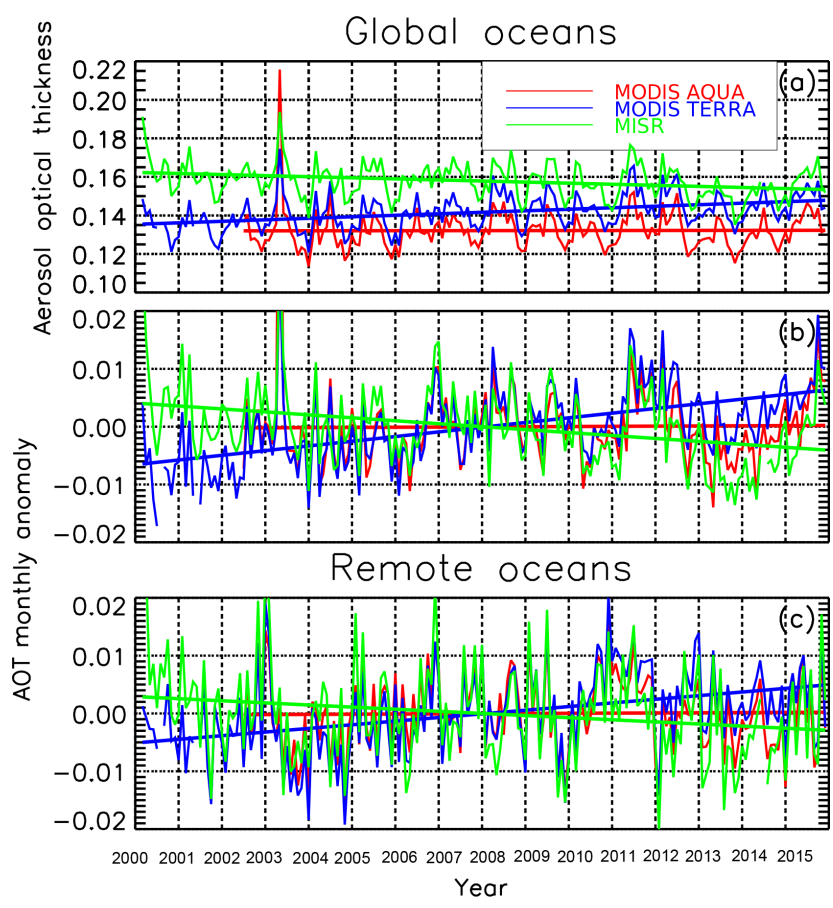

Figure 3. (a) Monthly averaged global AOTs derived using MODIS C6 DT aerosol products for Aqua (red), Terra (blue) and MISR (green). Straight lines are the linear fits for the monthly data. (b) Similar to (a), but for the deseasonalized, monthly averaged AOTs. (c) Similar to (b), but for the remote-ocean region as described in Table 3.

trends are found over the Mediterranean Sea (Fig. 4f) and the east coast of North America (Fig. 4g), again from all three datasets. These findings are also consistent with what has been reported by Toth et al. (2016) with the use of CALIOP data. Also, despite the differences in sampling methods as well as calibration, regional trends from MISR are similar to trends derived using both Aqua and Terra MODIS DT data.

\section{SWARE trends}

In Sect. 3, changes in aerosol concentrations over global oceans are studied with respect to AOT trends. The temporal variations in aerosol concentrations could also introduce changes in TOA SW fluxes and thus can be detected using collocated MODIS and CERES (SSF and ES-8) observations. In this section, the SWARE trends derived using MODIS and CERES (SSF and ES-8) data are explored and are intercompared with AOT trends as mentioned in the previous section.

\subsection{SWARE trend analysis using collocated MODIS and CERES data}

In several past studies, SWARE values are derived using collocated CERES and MODIS data based on Eq. (1) (e.g., 


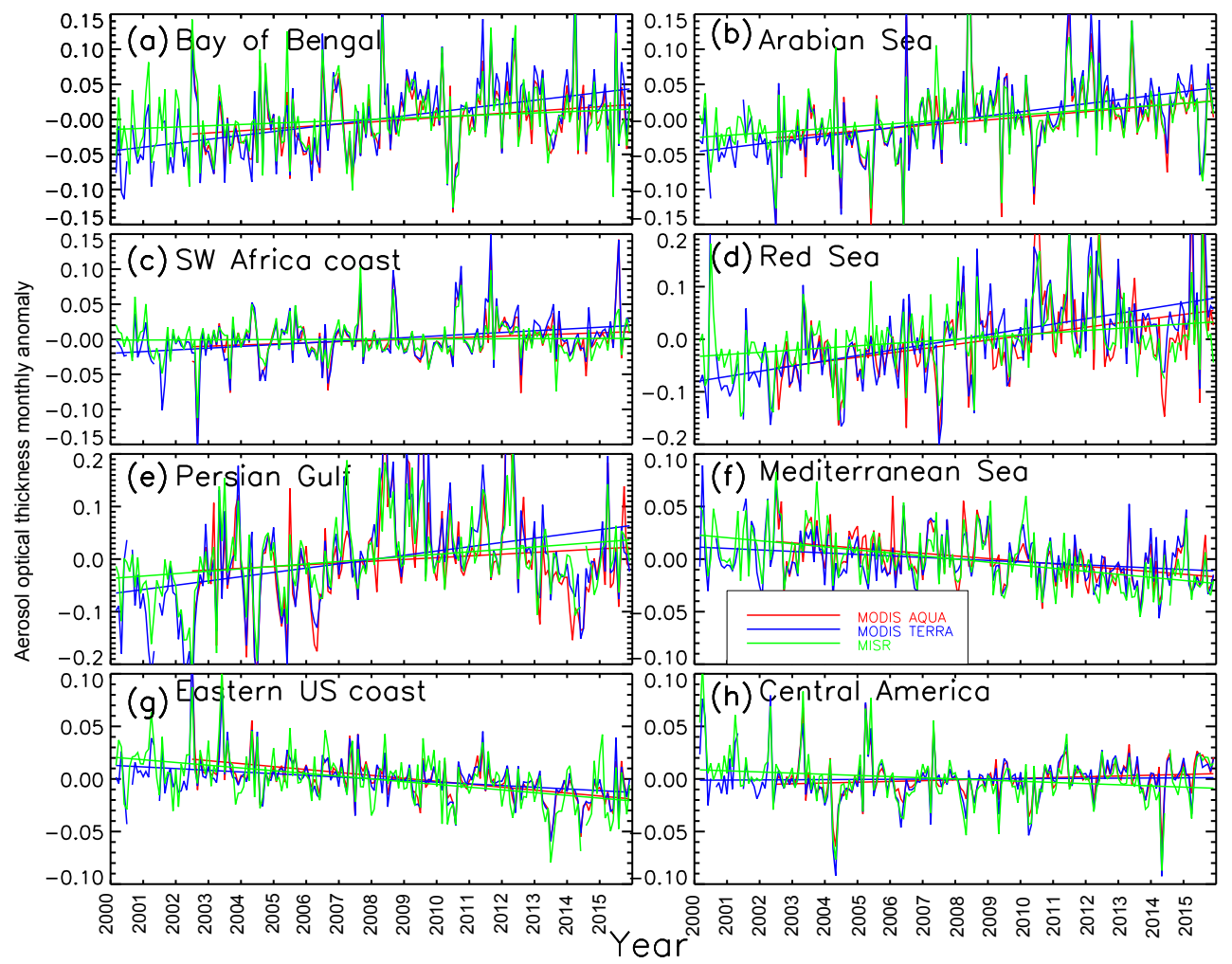

Figure 4. The deseasonalized, monthly and regionally averaged AOTs for eight selected regions utilizing MODIS C6 DT and MISR aerosol products. Straight lines are linear fits to the monthly data.

Loeb and Kato, 2002; Loeb et al., 2003; Zhang et al., 2005b; Christopher and Zhang., 2002a; b):

$\mathrm{SWARE}=F_{\text {clear }}-F_{\text {aero }}$,

where $F_{\text {clear }}$ represents the TOA SW flux over aerosol and cloud-free skies and $F_{\text {aero }}$ represents the TOA SW flux over cloud-free skies. Taking the derivative of Eq. (1) with respect to time, we can obtain Eq. (2):

$\frac{\partial \mathrm{SWARE}}{\partial t}=\frac{\partial F_{\text {clear }}}{\partial t}-\frac{\partial F_{\text {aero }}}{\partial t}$.

Here $\partial \mathrm{SWARE} / \partial t$ represents the trend in SWARE. $\partial F_{\text {aero }} / \partial t$ represents a temporal change in TOA-observed $\mathrm{SW}$ flux over cloud-free skies. $\partial F_{\text {clear }} / \partial t$ represents a change in background TOA SW energy over cloud and aerosol free skies. Here, $F_{\text {clear }}$ is a function of viewing geometry (e.g., solar zenith angle) and near-surface wind patterns. By deseasonalizing CERES SW flux data, we can remove the solar zenith angle effect. Also, by using monthly averages of instantaneous retrievals, we assume that there is no viewing zenith or azimuth dependency with respect to time. If we further assume that the changes in near-surface wind patterns are negligible for the study period, the $\partial F_{\text {clear }} / \partial t$ term can be assumed to be near-zero (the impact of near-surface wind speed on the SWARE trend is explored in a later section).
Thus, we can rewrite Eq. (2) as

$\frac{\partial \mathrm{SWARE}}{\partial t}=\frac{-\partial F_{\text {aero }}}{\partial t}$.

As suggested from Eq. (3), the trends in SWARE can be directly estimated from the temporal variations in SSF/ES-8 TOA SW flux from CERES over cloud-free skies (less than $1 \%$ cloud fraction and larger than $99 \% \mathrm{CP}$ ). This approach avoids the need to estimate $F_{\text {clear }}$, which cannot be observed and can only be derived through radiative transfer calculations (Christopher, 2011) or extrapolation (e.g., there is always a positive definite AOT).

The cloud-free TOA SW fluxes are obtained from CERES (SSF and ES-8) data in this study. This is accomplished by utilizing the collocated MODIS-CERES (SSF and ES8) dataset. As mentioned in Sect. 2, only those MODIS observations over cloud-free scenes $(\mathrm{CF}<1 \%$ and $\mathrm{CP}>$ $99 \%$ ) are used for this analysis as SW flux is sensitive to cloud contamination (Zhang et al., 2005a, b). However, filtering the MODIS datasets with such strict cloud fraction criteria significantly reduces the data volume, which may lead to a sampling bias when working with the MODISCERES dataset (e.g., Zhang and Reid, 2009). Therefore, all MODIS-CERES datasets have been averaged into seasons as opposed to monthly averages. In addition, the MODISCERES collocated observations are gridded into $2^{\circ} \times 2^{\circ}$ 
(latitude/longitude) grids to further alleviate the sampling bias produced by the data reduction in the MODIS-CERES dataset.

Figure 5 shows the spatial distributions of AOT and cloudfree CERES TOA SW flux over global oceans using collocated MODIS-CERES data (2000-2015 for Terra and 20022015 for Aqua). Comparing Fig. 5a and b with Fig. 2a and b, Terra (5a) and Aqua (5b) AOT plots generated using the collocated MODIS-CERES data are similar to the spatial distributions of AOT generated using the original Terra and Aqua C6 MODIS DT data. Figure 5e and $\mathrm{f}$ show the gridded cloudfree CERES SSF TOA SW fluxes for Terra and Aqua, respectively. It is interesting to note that, although they are from two different instruments that measure different physical quantities (narrow band vs. broadband energy; dependent vs. independent of forward calculations of MODIS), the spatial distributions of MODIS AOT and cloud-free CERES SSF TOA $\mathrm{SW}$ flux $\left(\mathrm{SW}_{\mathrm{ssf}}\right)$ show remarkably similar patterns.

Similar to Fig. 5e and f, Fig. 5c and d show the gridded cloud-free TOA SW fluxes for Terra and Aqua, respectively, but with the use of CERES ES-8 SW fluxes. Again, the spatial patterns of cloud-free CERES ES-8 TOA $\mathrm{SW}$ flux $\left(\mathrm{SW}_{\mathrm{es} 8}\right)$ highly correlate with AOT spatial patterns. Nevertheless, an overall difference in CERES SSF and ES-8 TOA SW fluxes is clearly observable (Fig. 5g and $\mathrm{h}$ ), and $\mathrm{SW}_{\text {ssf }}$ values are generally $8-9 \mathrm{~W} \mathrm{~m}^{-2}$ higher than $\mathrm{SW}_{\mathrm{es} 8}$ values. Smaller than average differences in cloud-free TOA SW fluxes between the two products can be seen over dust-aerosol-polluted regions such as the northwest coast of Africa, while larger than average differences are found over regions such as the northeast coast of Asia and Southeast Asia, where other type of aerosol particles dominate. For illustrative purposes, data counts for each $2 \times 2^{\circ}$ (latitude/longitude) bin that are used to create Fig. 5a-h are also shown in Fig. 5i and j for Terra and Aqua, respectively.

The relationship between AOT and cloud-free TOA SW flux values from Fig. 5 is also evaluated in Figs. 6 and 7 and Table 4. As suggested from Fig. 6a (Aqua) and c (Terra), multiyear means of AOTs and $\mathrm{SW}_{\text {ssf }}$ values share a highly correlated (correlations of 0.72 and 0.73 for Aqua and Terra data, respectively), nonlinear relationship. Similar but higher correlations between multiyear mean AOT and SW flux values are also found when using CERES ES-8 data (correlations of 0.83 and 0.87 for Aqua and Terra data, respectively) as shown in Fig. 7a (Aqua) and c (Terra).

Figure $6 \mathrm{~b}$ shows the Aqua MODIS AOT and Aqua $\mathrm{SW}_{\text {ssf }}$ relationship (nonlinear) for five selected regions that have high regional AOT values (e.g., maximum bin-averaged AOT $>0.3$ ), including the southwest and northwest coasts of Africa, coastal China, the Indian Bay of Bengal and the Arabian Sea. In particular, a much lower slope of $37.9 \mathrm{~W} \mathrm{~m}^{-2}$ AOT $^{-1}$ is found for the southwest coast of Africa when comparing with the other four regions. A similar pattern is observed for using Terra CERES SSF data (slope of $42.5 \mathrm{~W} \mathrm{~m}^{-2} \mathrm{AOT}^{-1}$ for the southwest coast of Africa) as
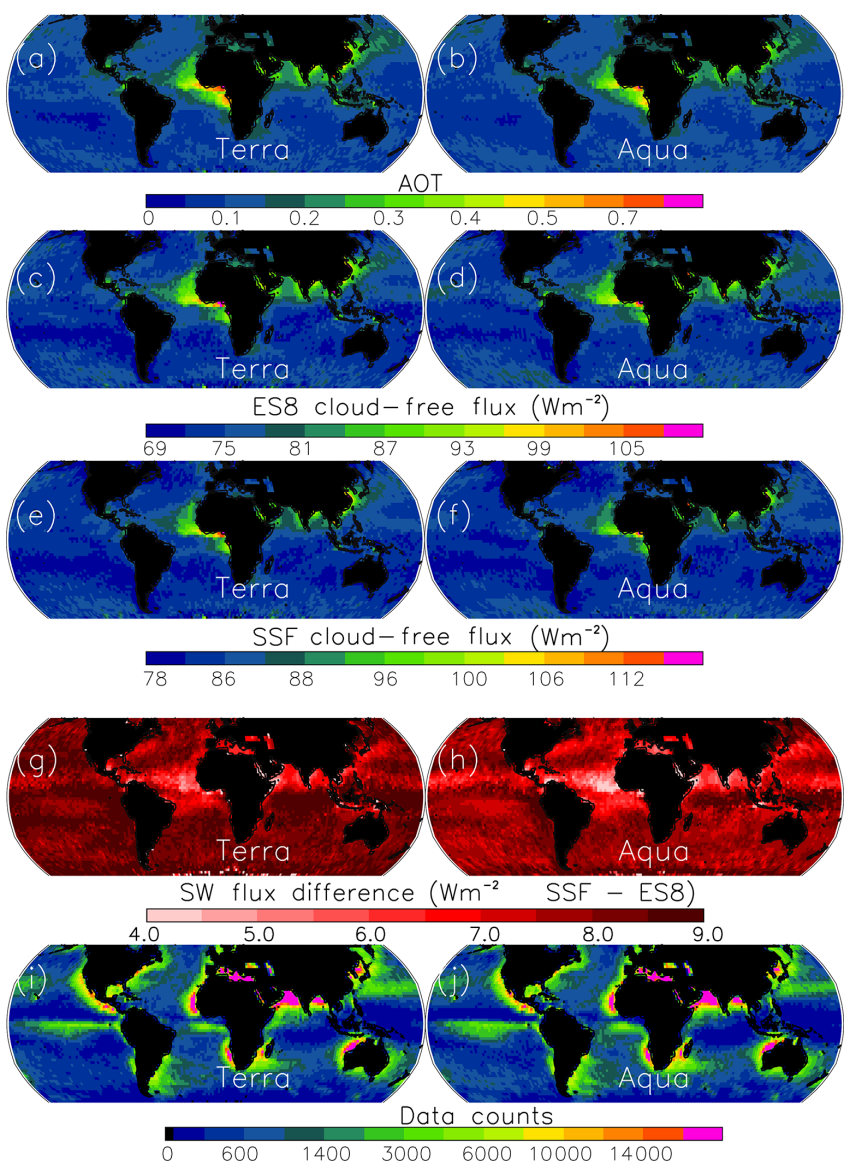

Figure 5. (a) The spatial distribution of seasonally averaged AOTs using Terra MODIS DT AOT data from the collocated Terra MODIS-CERES dataset for the study period of 2000-2015, at a spatial resolution of $2^{\circ} \times 2^{\circ}$ (latitude/longitude). (b) Similar to (a), but using the collocated Aqua MODIS-CERES dataset for the study period of 2002-2015. (c) Seasonally averaged CERES ES-8 cloud-free SW flux constructed using the collocated Terra MODISCERES dataset for the study period of 2000-2015. (d) Similar to (c), but using the collocated Aqua MODIS-CERES dataset for the study period of 2002-2015. (e-f) Similar to (c and d), but for the seasonally averaged CERES SSF cloud-free SW fluxes. (g) Difference between cloud-free SW flux from (e) and (c). (h) Similar to (g), but for Aqua. (i) Collocated Terra MODIS-CERES data counts for every $2^{\circ} \times 2^{\circ}$ (latitude/longitude) bin. (j) Similar to (i), but for Aqua.

well as for using both Aqua and Terra CERES ES-8 data (slopes of 39.9 and $43.8 \mathrm{~W} \mathrm{~m}^{-2} \mathrm{AOT}^{-1}$ for Aqua and Terra, respectively, for the southwest coast of Africa). Note that the slope of AOT and SW flux is a measure of (and inversely proportional to) the instantaneous SW aerosol direct forcing efficiency. Smoke aerosol particles dominate high AOTs for the southwest coast of Africa, while other regions are also influenced by non-smoke aerosols such as dust aerosol particles. Thus, Figs. 6 and 7 suggest a lower SW forcing efficiency (in magnitude) for biomass burning aerosols, in part 
Table 4. Instantaneous SW aerosol direct forcing efficiencies estimated based on the multiyear means (2000-2015 for Terra and 2002-2015 for Aqua) as well as for December-May and June-November seasons using both CERES SSF and ES-8 datasets. Forcing efficiencies are calculated for selected regions that have the maximum $2 \times 2^{\circ}$ (latitude/longitude) bin-averaged AOT $>0.3$, as well as for global oceans. The multiyear mean AOT and SWARE values are estimated using data from all valid bins. Note that values from this table are estimated under CERES cloud-free (less than $1 \%$ cloud fraction and larger than $99 \% \mathrm{CP}$ ) skies and thus regional and global AOT values may be different from the estimates as shown in Table 2.

\begin{tabular}{|c|c|c|c|c|c|c|c|c|c|c|}
\hline & \multicolumn{2}{|c|}{$\begin{array}{l}\text { Dec-May } \\
\left(\mathrm{W} \mathrm{m}^{-2} \mathrm{AOT}^{-1}\right)\end{array}$} & \multicolumn{2}{|c|}{$\begin{array}{l}\text { Jun-Nov } \\
\left(\mathrm{W} \mathrm{m}^{-2} \mathrm{AOT}^{-1}\right)\end{array}$} & \multicolumn{2}{|c|}{$\begin{array}{l}\text { Multi-year mean } \\
\left(\mathrm{W} \mathrm{m}^{-2} \mathrm{AOT}^{-1}\right)\end{array}$} & \multicolumn{2}{|c|}{$\begin{array}{l}\text { Multi-year mean } \\
\text { AOT }(0.55 \mu \mathrm{m})\end{array}$} & \multicolumn{2}{|c|}{$\begin{array}{l}\text { Multi-year mean } \\
\text { SWARE }\left(\mathrm{W} \mathrm{m}^{-2}\right)\end{array}$} \\
\hline & $\begin{array}{l}\text { Aqua } \\
\text { SSF/ } \\
\text { ES-8 }\end{array}$ & $\begin{array}{l}\text { Terra } \\
\text { SSF/ } \\
\text { ES-8 }\end{array}$ & $\begin{array}{l}\text { Aqua } \\
\text { SSF/ } \\
\text { ES-8 }\end{array}$ & $\begin{array}{l}\text { Terra } \\
\text { SSF/ } \\
\text { ES-8 }\end{array}$ & $\begin{array}{l}\text { Aqua } \\
\mathrm{SSF} / \\
\mathrm{ES}-8\end{array}$ & $\begin{array}{l}\text { Terra } \\
\text { SSF/ } \\
\text { ES-8 }\end{array}$ & $\begin{array}{l}\text { Aqua } \\
\mathrm{SSF} / \\
\mathrm{ES}-8\end{array}$ & $\begin{array}{l}\text { Terra } \\
\text { SSF/ } \\
\text { ES-8 }\end{array}$ & $\begin{array}{l}\text { Aqua } \\
\mathrm{SSF} / \\
\mathrm{ES}-8\end{array}$ & $\begin{array}{l}\text { Terra } \\
\text { SSF/ } \\
\text { ES-8 }\end{array}$ \\
\hline Africa & $-54.0 /$ & $-52.7 /$ & $-59.5 /$ & $-61.1 /$ & $-54.3 /$ & $-54.4 /$ & $0.190 /$ & $0.205 /$ & $-10.3 /$ & $-11.1 /$ \\
\hline (NW Coast) & -67.0 & -63.0 & -75.2 & -75.9 & -65.9 & -63.0 & 0.190 & 0.205 & -12.5 & -12.9 \\
\hline Africa & N/A/ & N/A/ & $-40.6 /$ & $-43.0 /$ & $-37.9 /$ & $-42.5 /$ & $0.160 /$ & $0.158 /$ & $-6.1 /$ & $-6.7 /$ \\
\hline (SW Coast) & N/A & N/A & -44.3 & -45.0 & -39.9 & -43.8 & 0.160 & 0.158 & -6.4 & -6.9 \\
\hline \multirow[t]{2}{*}{ Coastal China } & $-88.3 /$ & $-83.1 /$ & $-74.7 /$ & $-71.1 /$ & $-79.0 /$ & $-74.2 /$ & $0.294 /$ & $0.357 /$ & $-23.2 /$ & $-26.5 /$ \\
\hline & -83.8 & -82.8 & -74.5 & -74.0 & -79.4 & -79.7 & 0.294 & 0.357 & -23.3 & -28.4 \\
\hline \multirow[t]{2}{*}{ Arabian Sea } & $-61.8 /$ & $-65.7 /$ & $-60.0 /$ & $-60.6 /$ & $-61.5 /$ & $-65.0 /$ & $0.216 /$ & $0.238 /$ & $-13.3 /$ & $-15.5 /$ \\
\hline & -75.2 & -74.9 & -76.0 & -76.5 & -75.9 & -77.3 & 0.216 & 0.238 & -16.3 & -18.4 \\
\hline \multirow[t]{2}{*}{ Bay of Bengal } & $-66.3 /$ & $-52.7 /$ & $-68.4 /$ & $-58.4 /$ & $-74.8 /$ & $-52.2 /$ & $0.261 /$ & $0.295 /$ & $-19.5 /$ & $-15.4 /$ \\
\hline & -69.3 & -63.4 & -74.8 & -67.8 & -80.1 & -63.1 & 0.261 & 0.295 & -20.9 & -18.6 \\
\hline \multirow[t]{2}{*}{ Global Oceans } & $-58.7 /$ & $-57.3 /$ & $-56.5 /$ & $-53.7 /$ & $-61.0 /$ & $-57.5 /$ & $0.116 /$ & $0.116 /$ & $-7.1 /$ & $-6.7 /$ \\
\hline & -58.0 & -59.6 & -59.4 & -57.2 & -57.7 & -58.2 & 0.116 & 0.116 & -6.7 & -6.8 \\
\hline
\end{tabular}
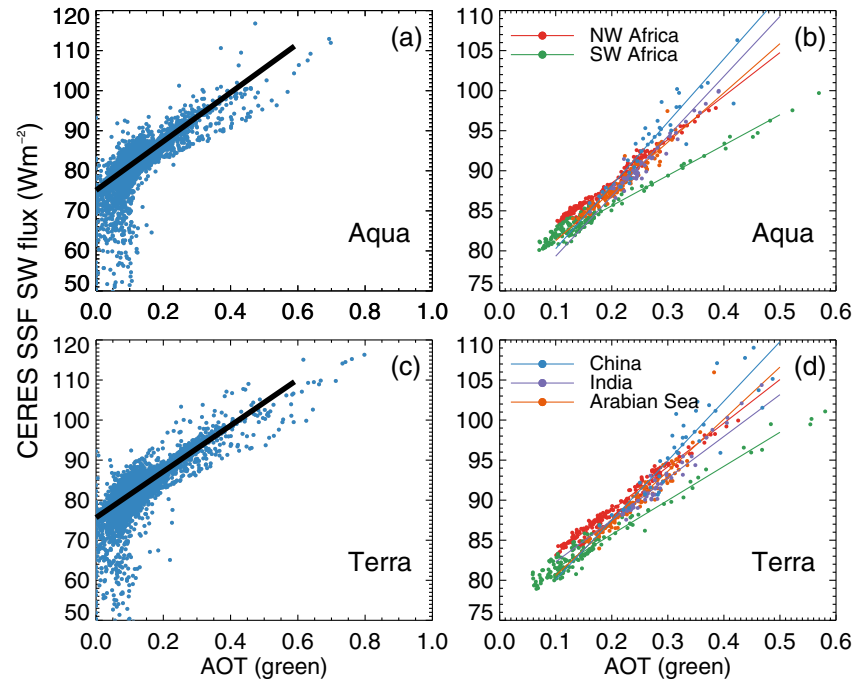

Figure 6. (a) Scatterplot of Aqua MODIS AOT vs. CERES SSF SW flux (cloud-free, at a $2^{\circ} \times 2^{\circ}$ resolution) using data as shown in Fig. 5. Color lines are for selected regions, and the thick black line is for global oceans. (b) Similar to (a), but for five selected regions that have a maximum AOT $>0.3$ as indicated from Fig. 5. (c) Similar to (a), but for Terra. (d) Similar to (b), but for Terra.

due to a stronger absorption at the visible spectrum (e.g., Remer et al., 2005).

We have further explored the topic by estimating SW aerosol forcing efficiencies for the December-May and June-November seasons as shown in Table 4. As indicated in Table 4, SW aerosol direct forcing efficiencies may experience a seasonal dependency such as over coastal China. For
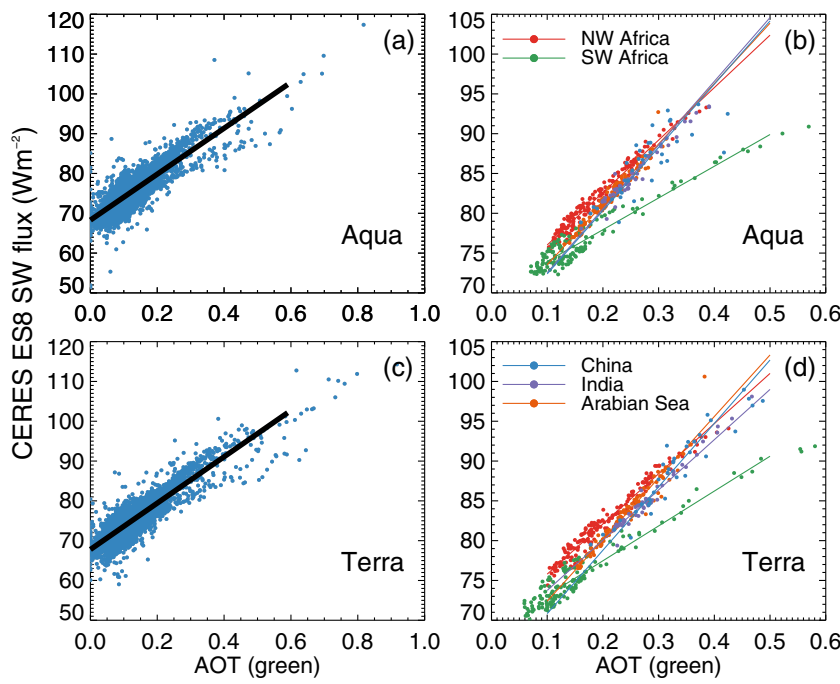

Figure 7. Similar to Fig. 6, but for using collocated MODIS and CERES ES-8 cloud-free SW flux data.

example, a CERES-SSF-based aerosol SW forcing efficiency value of $-88.3 \mathrm{~W} \mathrm{~m}^{-2}$ per Aqua MODIS AOT is found for coastal China for the December-May period. A lower value (CERES-SSF-based) of $-74.7 \mathrm{~W} \mathrm{~m}^{-2}$ per Aqua MODIS AOT is found for the June-November season for the same region. Similar conclusions can also be found using Terra data as well as using CERES ES-8 data. The seasonal dependency in SW aerosol forcing efficiency is not surprising for coastal China, as dust aerosols are expected for the spring season, while pollutant and smoke aerosols likely dominate for the June-November study period (Zhang et al., 2017). 


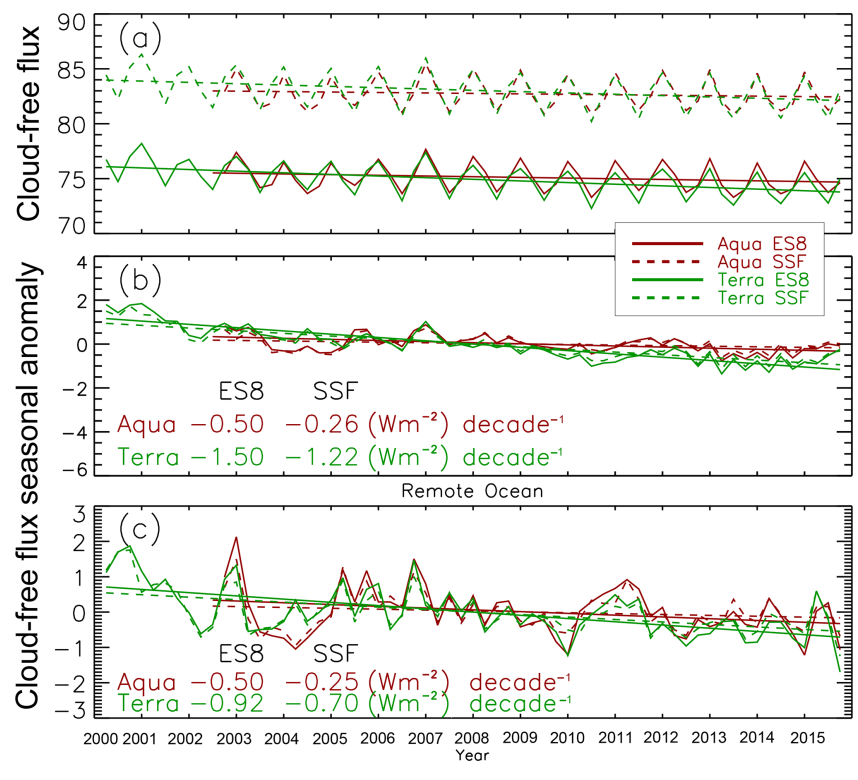

Figure 8. (a) Time series of seasonally averaged, cloud-free SW fluxes over global oceans utilizing the collocated MODIS-CERES (SSF/ES-8) datasets for Terra (green) and Aqua (red). (b) Similar to (a) but for the deseasonalized cloud-free sky anomalies. (c) Similar to (b), but using data from the remote-ocean region.

In comparison, less seasonally based changes are found for the Arabian Sea region, which may be plausibly linked to less significant temporal variation in aerosol speciation over the region. Also indicated in Table 4, the derived SWARE has a strong regional dependency, while the multiyear averaged SWARE is around -6 to $-7 \mathrm{Wm}^{-2}$ for the southwest coast of Africa; over coastal China, SWARE values of below $-20 \mathrm{~W} \mathrm{~m}^{-2}$ are found. Note that this conclusion remains unchanged regardless of whether Terra or Aqua data are used or whether CERES ES-8 or SSF ADMs are applied.

Over global oceans, the multiyear mean instantaneous SW aerosol direct forcing efficiencies are estimated to be -61 $(-58)$ and $-58(-58) \mathrm{W} \mathrm{m}^{-2} \mathrm{AOT}^{-1}$ using Aqua and Terra CERES SSF (ES-8) data, respectively. Those numbers are lower than $-70 \mathrm{~W} \mathrm{~m}^{-2}$ per AOT, which is reported in a previous study (Christopher and Jones, 2008). We suspect that the differences in forcing efficiency values may be introduced by different data screening methods as well as a much longer study period. Nevertheless, using estimated forcing efficiencies as well as AOTs (Table 4), the global mean (14 years of Aqua and 16 years of Terra data) over-ocean SWARE values are found to be around $-7 \mathrm{~W} \mathrm{~m}^{-2}$ regardless of datasets (Terra or Aqua) and ADMs (SSF or ES-8) used. Note that regional and global mean AOTs as shown in Table 4 are derived using the collocated MODIS and CERES datasets, representing mean AOTs over CERES cloud-free skies. Thus, mean AOTs as reported in Table 4 are different from AOTs as included in Table 2.

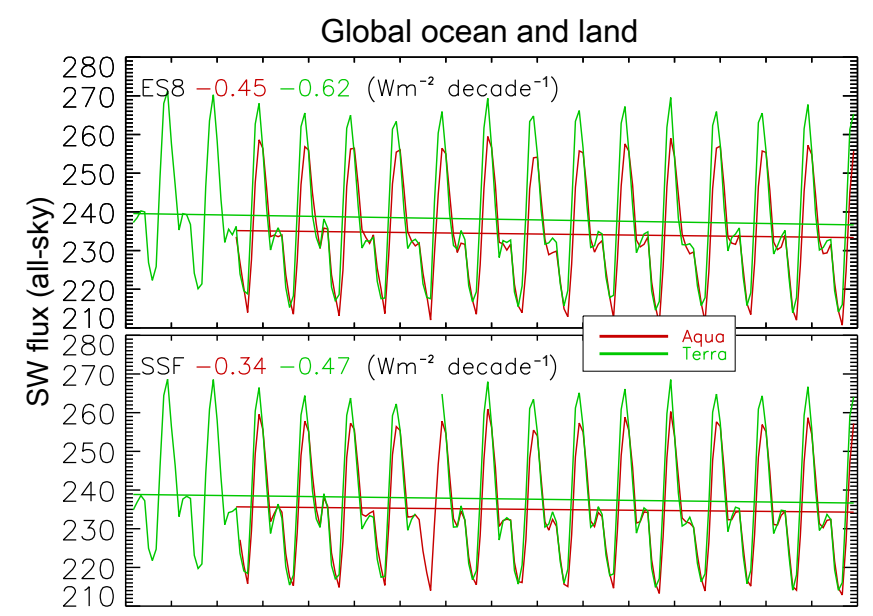

2000200120022003200420052006200720082009201020112012201320142015

$$
\text { Year }
$$

Figure 9. Time series of all-sky SW flux over the entire globe (land and ocean). The trends are calculated from monthly and globally averaged all-sky SW fluxes derived from the CERES SSF/ES-8 data. SW fluxes from all scenes including cloudy, clean, land and ocean are taken into account when calculating the monthly averages, which are gridded into a similar resolution as the collocated MODIS-CERES dataset $\left(2^{\circ} \times 2^{\circ}\right)$.

With the use of seasonally gridded SW flux values, the times series of cloud-free sky CERES SSF and ES8 TOA SW flux over global oceans are investigated and depicted in Fig. 8a, and the corresponding deseasonalized cloud-free sky flux anomalies are show in Fig. 8b. While Fig. 8a suggests an $\sim 8 \mathrm{~W} \mathrm{~m}^{-2}$ difference in mean overocean cloud-free sky SW flux between CERES SSF and ES8 products, a small difference in cloud-free sky SW flux trend of $0.2-0.3 \mathrm{~W} \mathrm{~m}^{-2}$ decade $^{-1}$ is found (Fig. 8b) between the two products for both Terra and Aqua data. For example, negative trends on the order of $-0.50 \mathrm{Wm}^{-2}$ and $-0.26 \mathrm{~W} \mathrm{~m}^{-2}$ decade $^{-1}$ are found for using Aqua CERES ES-8 and SSF products, respectively. Also, although larger cloud-free sky SW flux trends in magnitude are found when using Terra data, the difference between CERES-SSFbased and CERES-ES-8-based trends is still on the order of $0.2-0.3 \mathrm{~W} \mathrm{~m}^{-2}$ decade $^{-1}$ (cloud-free sky SW flux trend is $-1.50 \mathrm{~W} \mathrm{~m}^{-2}$ decade $^{-1}$ for Terra CERES ES-8 data and is $-1.22 \mathrm{~W} \mathrm{~m}^{-2}$ decade $^{-1}$ for Terra CERES SSF data). Figures $8 \mathrm{a}$ and $8 \mathrm{~b}$ may imply that different ADMs could significantly impact the derived SW flux values, but their impact on cloud-free sky TOA SW flux trends is rather marginal.

Similar to Sect. 3, we used CERES SW flux trends over the remote-ocean region as indicators of potential radiometric-calibration-related issues. The deseasonalized CERES SSF (ES-8) SW trends over the remote-ocean regions (Fig. 8c) seem to suggest plausible artificial trends of $-0.25(-0.50) \mathrm{W} \mathrm{m}^{-2} \mathrm{decade}^{-1}$ for Aqua and -0.70 $(-0.92) \mathrm{W} \mathrm{m}^{-2}$ decade $^{-1}$ for Terra, although these trends are 


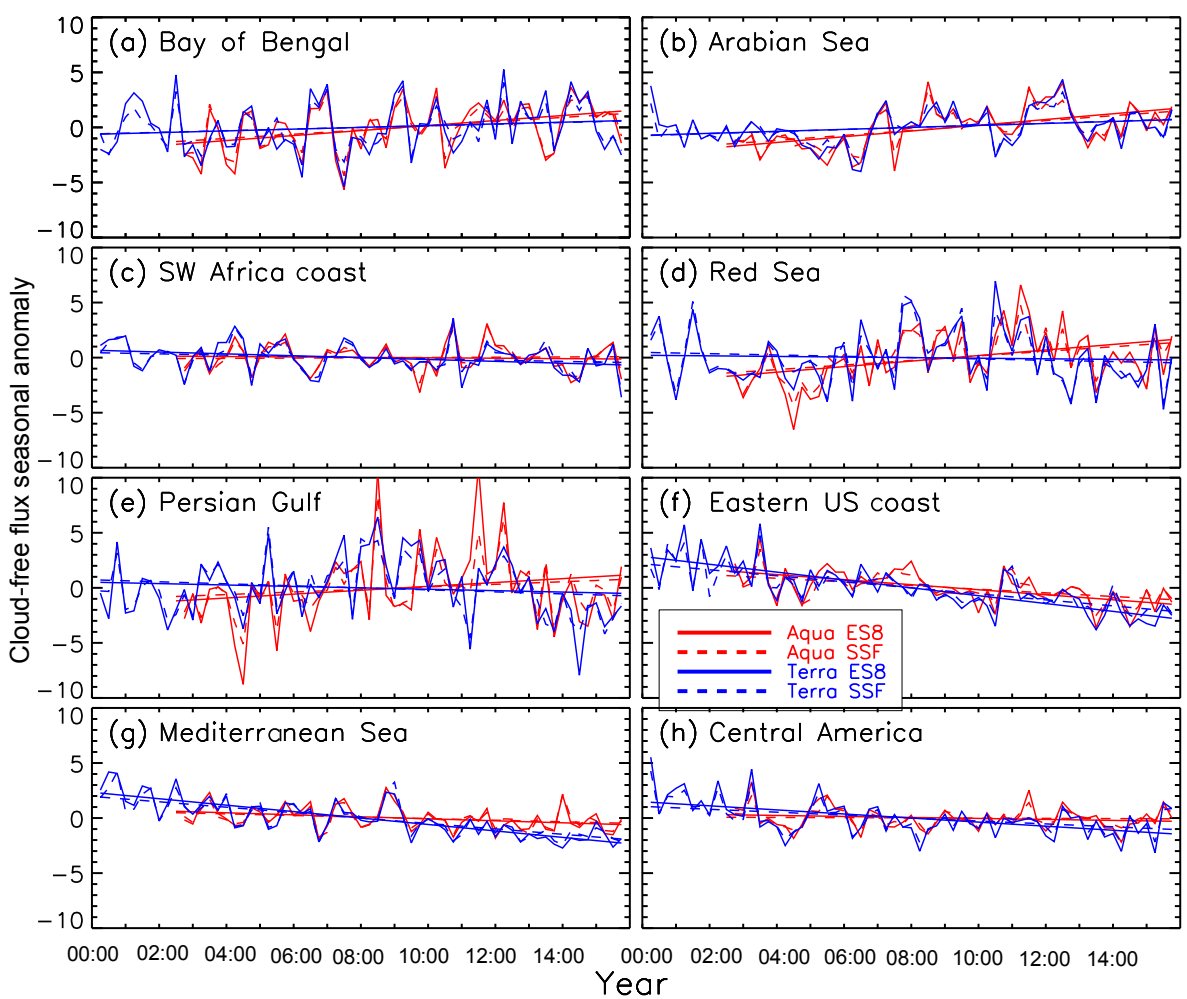

Figure 10. The temporal variations in deseasonalized, seasonally and regionally averaged CERES SSF/ES-8 cloud-free fluxes (seasonal anomaly) for eight selected regions, constructed using the collocated Aqua and Terra MODIS-CERES datasets. The blue lines represent the Terra-based analysis, while the red lines represent the Aqua-based analysis, and the solid lines represent the ES- 8 SW fluxes, whereas the SSF SW fluxes are depicted by dashed lines.

also affected by various uncertainties that are further explored in a later section. To examine if we could observe similar issues with the use of full CERES SSF/ES-8 datasets, Fig. 9 shows the all-sky CERES flux trend for the same study periods as Fig. 8. Decadal changes in SSF (ES-8) all-sky flux are around $-0.5(-0.7) \mathrm{Wm}^{-2}$ and $-0.4(-0.5) \mathrm{Wm}^{-2}$ for Terra and Aqua data, respectively. The Aqua all-sky flux trends are comparable to cloud-free sky trends for both SSF and ES-8 fluxes. However Terra-based all-sky trends are much lower in magnitude than the corresponding cloud-free flux, which indicates that cloud-free sky CERES SW energy may be more sensitive to calibration-related issues than allsky flux data for Terra-based analysis only. Nevertheless, if we account for the changes in SW trends over the remoteocean region, a negligible SW flux (SWARE) trend for Aqua and a negative (positive) SW flux (SWARE) trend of $-0.5 \mathrm{~W} \mathrm{~m}^{-2}$ decade $^{-1}\left(0.5 \mathrm{~W} \mathrm{~m}^{-2}\right.$ decade $\left.^{-1}\right)$ for Terra can be estimated for global oceans from the collocated MODISCERES data.

Although different cloud-free sky SW flux trends are found while using CERES ES- 8 data, after adjusting the detected trends with trends from the remote ocean region, a zero SW flux (SWARE) trend is found while using collocated Aqua ES-8 SW fluxes from the MODIS-CERES data, and a negative (positive) SW flux (SWARE) trend of $-0.6 \mathrm{~W} \mathrm{~m}^{-2} \mathrm{decade}^{-1}\left(0.6 \mathrm{~W} \mathrm{~m}^{-2} \mathrm{decade}^{-1}\right)$ is found using collocated Terra ES-8 SW fluxes from the MODIS-CERES collocated data, both are in good agreement with values estimated using the SSF SW fluxes from the same data. This again may seem to suggest that the impact of ADMs on SWARE trends over global oceans estimated from the collocated MODIS and CERES data are rather marginal.

A regional trend analysis for the deseasonalized cloud-free sky SSF and ES-8 SW fluxes is also carried out and presented in Table 3 and Fig. 10. Good agreement is shown between regional trends of AOTs (Fig. 4) and cloud-free fluxes (Fig. 10) for a majority of the regions (also shown in Table 3 for a direct comparison). For example, statistically significant positive (based on the MK method) SW flux trends are found over the Arabian Sea, and statistically significant negative trends are found over the Mediterranean Sea and eastern US coast for both Aqua- and Terra-based analyses. Also, over the east coast of China, although a near-positive trend is found for the study period of 2000-2006 (Terra), the SW flux trend turns negative from 2006 to 2015 (Fig. 11). This is consistent with what has been reported for AOT trends from a recent study (Zhang et al., 2017) as well as in Sect. 3. Here, a piecewise linear fit method from Tomé and Miranda (2004) is applied 


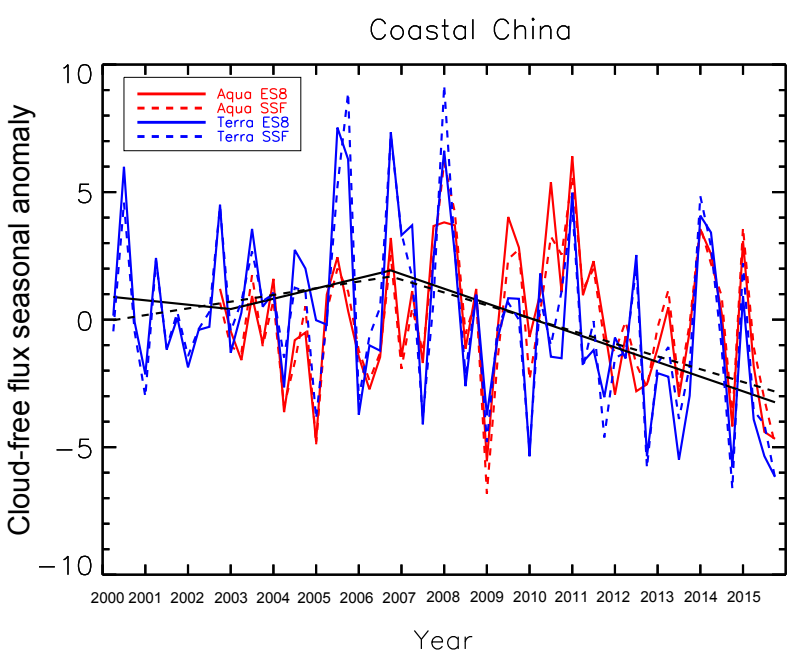

Figure 11. The deseasonalized, seasonally averaged cloud-free fluxes over coastal China derived utilizing the collocated MODISCERES (SSF/ES-8) datasets. Straight lines show piecewise linear fits for the study periods of 2000-2015 (Terra only).

to detect turning points in trends, similar to what is suggested by Zhang et al. (2017). Also, similar to Zhang et al. (2017), we assume a minimum of 36 months between any two detected turning points. For regions such as the Bay of Bengal, although positive SW flux trends are found, the trends are not statistically significant for one or all datasets.

Next, the grid-level AOT and cloud-free flux trends are derived from the collocated MODIS-CERES datasets as shown in Fig. 12. Figures 12a (Terra) and 12b (Aqua) depict the de-biased (applied corrections based on the estimate from the remote-ocean region) changes in deseasonalized AOT per year for each $4^{\circ} \times 4^{\circ}$ (latitude/longitude) grid (averaged from the $2^{\circ} \times 2^{\circ}$ latitude/longitude dataset) over the entire time period (all seasons and years combined). Figure 12e and $\mathrm{f}$ depict the grid-level CERES SSF SW flux trends over cloudfree skies similar to Fig. 12a and b. Similar to the AOT gridlevel analysis shown in Fig. 1, at least $60 \%$ of the data record in each grid are required to have valid AOT and SW flux trend values. Comparing between Aqua AOT (Fig. 12b) and CERES SSF cloud-free SW (Fig. 12f) trends, some similarity can be found. For example, positive trends are found, in both plots, over coastal India and the Arabian Sea regions, and negative trends are observable from Europe and the east coast of North America. A similar conclusion can also be reached when using Terra data (Fig. 12a and e) as well as when using CERES ES-8 data (Fig. 12c and d). Nevertheless, discrepancies can be found. For example, although the spatial distributions of AOT from both Terra and Aqua show similar patterns, differences between the spatial distributions of Terra and Aqua CERES cloud-free SW fluxes, regardless of the ADMs used, are clearly visible. Much larger regions with negative cloud-free SW flux trends are found for using Terra data. This may be a result of several possible issues

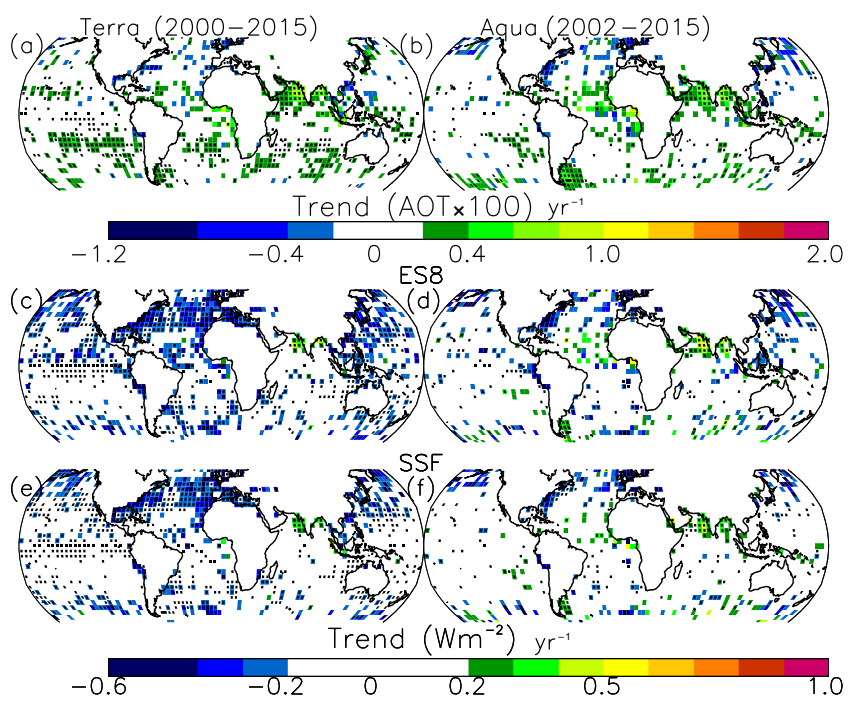

Figure 12. Spatial distribution of gridded AOT trends for (a) 16year Terra (2000-2015) and (b) 14-year Aqua (2002-2015) for every $4^{\circ} \times 4^{\circ}$ (latitude/longitude) bin derived from the collocated MODIS-CERES dataset. AOT trends are constructed using seasonally averaged AOTs. (c) Spatial distribution of cloud-free sky CERES ES-8 SW flux trends estimated using the collocated Terra MODIS-CERES data for the study period of 2000-2015. (d) Similar to (c), but using the collocated Aqua MODIS-CERES (ES-8) dataset for the study period of 2002-2015. (e-f) Similar to (c) and (d), but for using CERES SSF data. Grids with statistically significant AOT/clear-sky SW flux trends at the $95 \%$ confidence interval are shown in black dots.

such as SW flux outliers in the CERES dataset, the quality control applied to the CERES dataset or cloud contamination issues. Thus, this will be examined in the following section.

\subsection{Uncertainty in cloud-free flux trend analysis}

In this section, issues that could impact the derived SWARE trends are explored, which include changes in near-surface wind patterns, cloud contamination and uncertainties in the cloud-free SW flux trend estimates over the remote-ocean region (used as a proxy for radiometric calibration). Note that there are other uncertainty sources that may impact the derived CERES SW flux values, such as uncertainties in converting unfiltered to filtered radiances (Zhang et al., 2005b). However, temporal variations in those uncertainty sources are assumed to be negligible for this study, and thus those terms are not included in the trend uncertainty analysis.

\subsubsection{Baseline region (a proxy for radiometric calibration)}

As mentioned in Sect. 4.1, the TOA cloud-free SW flux trend over the remote-ocean region is used as an indicator of potential calibration-related issues. The selection of the remoteocean region boundaries is rather arbitrary, and thus the vari- 
Table 5. List of uncertainty sources (in $\mathrm{W} \mathrm{m}^{-2} \mathrm{decade}^{-1}$ ) for the estimated cloud-free SW flux trends.

\begin{tabular}{|c|c|c|c|c|}
\hline \multirow[t]{2}{*}{ Region/sensitivity test } & \multicolumn{2}{|l|}{ ES-8/SSF cloud-free flux trends $\left(\mathrm{W} \mathrm{m}^{-2}\right.$ decade $\left.^{-1}\right)$} & \multicolumn{2}{|c|}{$\mathrm{SD}\left(\mathrm{W} \mathrm{m}^{-2}\right.$ decade $\left.^{-1}\right)$} \\
\hline & $\begin{array}{l}\text { Terra } \\
\text { ES-8/SSF }\end{array}$ & $\begin{array}{l}\text { Aqua } \\
\text { ES-8/SSF }\end{array}$ & $\begin{array}{l}\text { Terra } \\
\text { ES-8/SSF }\end{array}$ & $\begin{array}{l}\text { Aqua } \\
\text { ES-8/SSF }\end{array}$ \\
\hline Global oceans & $-1.50 /-1.22$ & $-0.50 /-0.26$ & & \\
\hline $\begin{array}{l}\text { Remote ocean } \\
\text { region outline } \\
\text { Lat } 40^{\circ} \mathrm{S}-0^{\circ} \text {, long } 180-140^{\circ} \mathrm{W} \\
\text { Lat } 40^{\circ} \mathrm{S}-0^{\circ} \text {, long } 170^{\circ} \mathrm{E}-150^{\circ} \mathrm{W} \\
\text { Lat } 40^{\circ} \mathrm{S}-0^{\circ} \text {, long } 170-130^{\circ} \mathrm{W} \\
\text { Lat } 50-10^{\circ} \mathrm{S} \text {, long } 180-140^{\circ} \mathrm{W} \\
\text { Lat } 30^{\circ} \mathrm{S}-10^{\circ} \mathrm{N} \text {, long } 180-140^{\circ} \mathrm{W}\end{array}$ & $\begin{array}{l}-0.92 /-0.70 \\
-1.00 /-0.79 \\
-0.84 /-0.63 \\
-0.89 /-0.67 \\
-1.08 /-0.81\end{array}$ & $\begin{array}{l}-0.50 /-0.25 \\
-0.47 /-0.23 \\
-0.43 /-0.20 \\
-0.43 /-0.25 \\
-0.62 /-0.29\end{array}$ & $0.09 / 0.08$ & $0.08 / 0.03$ \\
\hline $\begin{array}{l}\text { Global ocean/variation in CF \% } \\
0|<0.5|<1|<2|<3|<4|<5\end{array}$ & $\begin{array}{l}-1.46|-1.49|-1.50|-1.51|-1.54|-1.56|-1.57 \\
-1.22|-1.24|-1.24|-1.25|-1.27|-1.29|-1.30\end{array}$ & $\begin{array}{l}-0.46|-0.51|-0.52|-0.54|-0.54|-0.55|-0.55 \\
-0.24|-0.28|-0.28|-0.28|-0.27|-0.26|-0.26\end{array}$ & $0.04 / 0.03$ & $0.03 / 0.01$ \\
\hline $\begin{array}{l}\text { Global ocean/variation in CP \% } \\
100|>99|>98|>97|>96 \mid>95\end{array}$ & $\begin{array}{l}-1.44|-1.48|-1.49|-1.49|-1.49 \mid-1.49 \\
-1.13|-1.26|-1.30|-1.32|-1.34 \mid-1.35\end{array}$ & $\begin{array}{l}-0.54|-0.55|-0.54|-0.53|-0.52 \mid-0.52 \\
-0.29|-0.23|-0.20|-0.17|-0.16 \mid-0.15\end{array}$ & $0.02 / 0.08$ & $0.01 / 0.05$ \\
\hline $\begin{array}{l}\text { Global ocean/cirrus contamination } \\
\text { MODIS-CERES-CALIOP } \\
\text { MODIS-CERES-CALIOP (cirrus filtered) }\end{array}$ & & $\begin{array}{l}-0.59 /-0.33 \\
-0.48 /-0.26\end{array}$ & & $0.08 / 0.05$ \\
\hline $\begin{array}{l}\text { ADMs/wind speeds } \\
\text { Global full data record (ES-8) } \\
\text { Global full data record (SSF) }\end{array}$ & $\begin{array}{l}-1.50 \\
-1.22\end{array}$ & $\begin{array}{l}-0.50 \\
-0.26\end{array}$ & $0.20 / 0.20$ & $0.17 / 0.17$ \\
\hline Overall uncertainty & & & $\begin{array}{l}0.3 / 0.3 \\
\mathrm{Wm}^{-2} \\
\text { decade }^{-1}\end{array}$ & $\begin{array}{l}0.2 / 0.2 \\
\mathrm{~W} \mathrm{~m}^{-2} \\
\text { decade }^{-1}\end{array}$ \\
\hline
\end{tabular}

ations in TOA cloud-free CERES SW flux trends over the remote-ocean region are investigated by modifying the regional boundaries for four different scenarios as shown in Table 5. Alternate remote-ocean regions are chosen by shifting the original boundaries by $10^{\circ}$ in each direction. The variations in estimated CERES SSF (ES-8) SW flux trends, which correspond to standard deviation (SD) values of $0.08(0.09)$ and $0.03(0.08) \mathrm{W} \mathrm{m}^{-2}$ decade $^{-1}$ for Terra and Aqua, respectively, provide the first-order estimation of the potential variations in the estimated SW trends over the remote oceans.

\subsubsection{Cloud fraction}

Similarly, the cloud-free SW flux trends over global oceans are estimated through varying MODIS cloud fractions from 0 to $5 \%$ as indicated in Table 5. The SD of the data spread is found to be less than $0.1 \mathrm{~W} \mathrm{~m}^{-2}$ decade $^{-1}$ for both Terraand Aqua-based CERES SSF and ES-8 SW flux trend analyses, suggesting that cloud contamination has a minor effect on the trend analysis. This conclusion is also confirmed by a sensitivity test by estimating SSF and ES- 8 SW flux trends through varying $\mathrm{CP}$ values from 95 to $100 \%$.

\subsubsection{Thin cirrus}

Through the use of CALIOP observations, several studies suggest that OTC cloud contamination exists in MODISdetected totally cloud-free skies (e.g., Toth et al., 2013). Therefore, the impacts of OTC clouds are evaluated by collocating CALIOP cloud layer data with the already collocated Aqua MODIS and CERES data pairs. All CALIOP obser- vations are spatiotemporally collocated with the CERES observations if the temporal difference in the two sensor's scan times is less than or equal to $5 \mathrm{~min}$ and if the center of the CALIOP observations lies within $0.3^{\circ}$ (latitude/longitude) of the center of the CERES observations. All collocated CERES observations are assigned a cirrus cloud flag depending on whether any of the collocated CALIOP pixels was found to be contaminated by cirrus clouds. The global averaging process is once again performed using the collocated MODISCERES-CALIOP observations. CERES observations which are contaminated by cirrus clouds, as identified by CALIOP data, are removed from the averaging process. The resulting global AOT and cloud-free flux trends are presented in Fig. 13a and b, respectively, for using both CERES ES-8 and SSF SW fluxes. For comparison, the MODIS-CERES trends are also shown (red) over the same time period (summer 2006-fall 2015). Despite differences in globally averaged AOTs, the global TOA SW flux trends derived using the two different datasets are remarkably similar. The SD in global cloud-free CERES SSF flux trend calculations due to OTC is less than $0.1 \mathrm{Wm}^{-2}$ decade $^{-1}$, as shown in Table 5 . Thus, OTC clouds may have a minimal impact on the derived cloud-free SW flux trends.

\subsubsection{Surface wind and ADMs}

The uncertainty in cloud-free SW flux trends are also examined as functions of surface wind speeds and ADMs. As mentioned previously, the effect of surface wind speed is included in CERES ADMs (used in the SSF dataset). Thus, the SWARE trends derived from the CERES SSF datasets 
Table 6. Intercomparison of AOT (AOT decade $\left.{ }^{-1}\right)$ and SW flux $\left(\mathrm{W} \mathrm{m}^{-2}\right.$ decade $\left.^{-1}\right)$ trends from this study as well as a few previous studies on both regional and global scales. Trends for the same regions as defined in Table 3 are shown.

\begin{tabular}{|c|c|c|c|c|c|c|c|c|}
\hline \multirow{3}{*}{ Region } & \multicolumn{2}{|c|}{$\begin{array}{l}\text { Zhang and Reid } \\
(2010) \\
\text { Terra MODIS C5 } \\
\text { Mar 2000-Dec } 2009\end{array}$} & \multicolumn{4}{|c|}{$\begin{array}{l}\text { This study } \\
\text { Terra MODIS C6 } \\
\text { Mar 2000-Dec } \\
2015\end{array}$} & $\begin{array}{l}\text { Toth } \\
\text { et al. (2016) } \\
\text { Aqua CALIOP } \\
\text { Cloud-free } \\
\text { Jun 2006-Dec } \\
2014\end{array}$ & $\begin{array}{l}\text { Alfaro- } \\
\text { Contreras } \\
\text { et al. (2016) } \\
\text { Aqua CALIOP } \\
\text { Above-cloud } \\
\text { Jun 2006-Dec } \\
2014\end{array}$ \\
\hline & \multicolumn{2}{|c|}{$\Delta$ AOT decade $^{-1}$} & \multicolumn{2}{|c|}{$\Delta$ AOT decade ${ }^{-1}$} & \multicolumn{2}{|c|}{$\begin{array}{l}\Delta \text { Cloud-free flux } \\
\mathrm{W} \mathrm{m}^{-2} \text { decade }^{-1} \\
(\mathrm{ES}-8 / \mathrm{SSF})\end{array}$} & $\Delta$ AOT decade $^{-1}$ & $\Delta$ AOT decade ${ }^{-1}$ \\
\hline & $\begin{array}{l}\text { w/o } \\
\text { correction }\end{array}$ & $\begin{array}{l}\text { w/ } \\
\text { correction }\end{array}$ & $\begin{array}{l}\text { w/o } \\
\text { correction }\end{array}$ & $\begin{array}{l}\text { w/ } \\
\text { correction }\end{array}$ & $\begin{array}{l}\text { w/o } \\
\text { correction }\end{array}$ & $\begin{array}{l}\text { w/ } \\
\text { correction }\end{array}$ & & \\
\hline Global ocean & 0.010 & 0.003 & 0.008 & 0.002 & $\begin{array}{l}-1.50 / \\
-1.22\end{array}$ & $\begin{array}{l}-0.58 / \\
-0.52\end{array}$ & 0.002 & 0.005 \\
\hline $\begin{array}{l}\text { Africa } \\
\text { (NW coast) }\end{array}$ & -0.006 & -0.013 & 0.009 & 0.003 & $\begin{array}{l}-1.79 / \\
-1.29\end{array}$ & $\begin{array}{l}-0.87 / \\
-0.59\end{array}$ & -0.014 & 0.0007 \\
\hline Bay of Bengal & 0.076 & 0.069 & 0.056 & 0.050 & $\begin{array}{l}0.79 / \\
0.75\end{array}$ & $\begin{array}{l}1.71 / \\
1.45\end{array}$ & 0.016 & 0.079 \\
\hline $\begin{array}{l}\text { Coastal } \\
\text { China }\end{array}$ & 0.069 & 0.062 & 0.007 & 0.001 & $\begin{array}{l}-2.51 / \\
-2.09\end{array}$ & $\begin{array}{l}-1.59 / \\
-1.39\end{array}$ & -0.017 & 0.01 \\
\hline $\begin{array}{l}\text { Arabian } \\
\text { Sea }\end{array}$ & 0.065 & 0.058 & 0.057 & 0.051 & $\begin{array}{l}0.90 / \\
0.94\end{array}$ & $\begin{array}{l}1.82 / \\
1.64\end{array}$ & 0.027 & 0.055 \\
\hline $\begin{array}{l}\text { Mediterranean } \\
\text { Sea }\end{array}$ & -0.009 & -0.016 & -0.014 & -0.020 & $\begin{array}{l}-2.93 / \\
-2.46\end{array}$ & $\begin{array}{l}-2.01 / \\
-1.76\end{array}$ & -0.006 & -0.010 \\
\hline $\begin{array}{l}\text { Africa } \\
\text { (SW coast) }\end{array}$ & 0.016 & 0.009 & 0.025 & 0.019 & $\begin{array}{l}-0.85 / \\
-0.57\end{array}$ & $\begin{array}{l}0.07 / \\
0.13\end{array}$ & 0.009 & 0.007 \\
\hline $\begin{array}{l}\text { North America } \\
\text { (East coast) }\end{array}$ & -0.008 & -0.015 & -0.016 & -0.022 & $\begin{array}{l}-3.57 / \\
-2.73\end{array}$ & $\begin{array}{l}-2.65 / \\
-2.03\end{array}$ & -0.013 & -0.02 \\
\hline $\begin{array}{l}\text { Remote } \\
\text { Ocean }\end{array}$ & 0.007 & 0 & 0.006 & 0 & $\begin{array}{l}-0.92 / \\
-0.70\end{array}$ & $0 / 0$ & & 0.005 \\
\hline
\end{tabular}

are used to investigate ADMs and surface wind speed related uncertainties in this study. Based on Table 3, the cloud-free sky SW flux trends derived from the CERES SSF SW flux are -0.26 and $-1.22 \mathrm{~W} \mathrm{~m}^{-2}$ decade $^{-1}$ for using Aqua and Terra datasets, respectively, and the numbers are -0.50 and $-1.50 \mathrm{~W} \mathrm{~m}^{-2}$ decade $^{-1}$ for using CERES ES- 8 data. Thus, the cloud-free SW flux trends derived using the CERES ES8 are on the order of $-0.25 \mathrm{~W} \mathrm{~m}^{-2}$ decade $^{-1}$ (corresponding to SD values of 0.20 and $0.17 \mathrm{~W} \mathrm{~m}^{-2}$ decade $^{-1}$ for Terra and Aqua, respectively) lower than the same trends derived using CERES SSF data for the same study period. The $0.25 \mathrm{~W} \mathrm{~m}^{-2}$ decade $^{-1}$ difference does indeed contain combined uncertainties from ADMs as well as the changes in surface wind speeds for both Terra and Aqua datasets.

Overall, the largest sources of uncertainty in the SWARE trend estimates are from ADMs/near-surface wind speed changes, while the impact of cloud contamination is rather minor. If we assume the SD values from Table 5 can be considered as uncertainties, an overall uncertainty in the trend analysis can be estimated based on Eq. (4) (Penner et al., 1994; Zhang et al., 2005b):
$U_{t}=e^{\left[\sum \log U_{i}^{2}\right]^{0.5}}$,

where $U_{t}$ is the overall uncertainty factor and $U_{i}$ is the uncertainty factor from each item in Table 5. The uncertainty factor is defined such that if the percentage uncertainty is $8 \%$, then the uncertainty factor is 1.08. As shown in Table 5, estimated from Eq. (4), the overall uncertainties for the SWARE trends estimated using CERES SSF data are 0.3 and $0.2 \mathrm{~W} \mathrm{~m}^{-2}$ decade $^{-1}$ for Terra- and Aqua-based analyses, respectively, shown also in Table 5. Note that similar numbers are also found by repeating the same exercise but using CERES ES-8 data as shown in Table 5.

\section{Comparison to other aerosol-related trend analyses}

Both AOT and SWARE trends are estimated in this study. Using CALIOP data from 2006 to 2014, Toth et al. (2016) studied AOT and aerosol vertical distribution trends over both land and oceans. Alfaro-Contreras et al. (2016) explored temporal variations in above-cloud AOT with the 

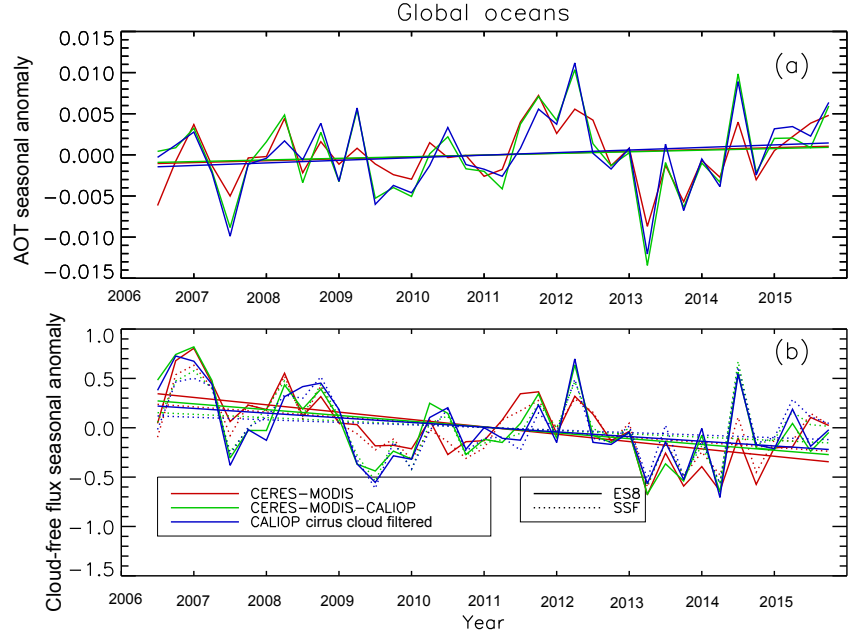

Figure 13. Global AOT trends derived from the (red) MODISCERES dataset, (green) MODIS-CERES-CALIOP dataset and (blue) MODIS-CERES-CALIOP dataset after filtering for cirrus clouds. Both CERES SSF and ES- 8 data are included. Time series have been derived utilizing seasonal AOT averages. CALIOP is used to locate and remove CERES observations contaminated with cirrus clouds. (b) Depicts the same thing as (a), except for the cloudfree flux. This analysis is carried out for the Aqua-based study only.

combined use of the Ozone Monitoring Instrument (OMI) and CALIOP data. Although different spectral widths (narrowband vs. broadband), different instruments (passive vs. active sensors) and different observing conditions (cloud-free skies vs. cloudy skies) are considered in different studies, it is interesting to intercompare trends derived from those studies, as shown in Table 6. Another reason for selecting these studies is because AOT trends for similar regions are reported.

Four studies are listed in Table 6, including passivebased AOT analysis (Zhang and Reid, 2010; this study), SWARE analysis (this study), CALIOP-based AOT analysis (Toth et al., 2016) and above-cloud AOT analysis (AlfaroContreras et al., 2016). It should be noted that only overocean data are used for the studies utilizing passive-based instruments (Zhang and Reid, 2010; current study). The estimated trends from the active-based studies (Alfaro-Contreras et al., 2016; Toth et al., 2016) included both land and ocean CALIOP data. Also, different data sampling, data screening and filtering methods are applied for different studies.

Table 6 includes estimates for global oceans and for selected regions as defined in Table 3 from all four studies. It is interesting to note that positive trends in AOT (both from passive and active methods), SWARE and above-cloud AOT are found over the Bay of Bengal and the Arabian Sea (Alfaro-Contreras et al., 2016). Negative trends are found, across all four studies, over the Mediterranean Sea and the eastern coast of the US. The cohesive results from studies using different instruments with varying methods, seem to add more fidelity to the trend analysis of this study.
Still, over coastal China, while Zhang and Reid (2010) reported a statistically significant positive AOT trend for the study period of 2000-2009, negative AOT trends are found from both this study (2002-2015) and Toth et al. (2016; for 2006-2014). Again, this is because a potential increase in aerosol loading for the early study period (2000-2007) continued with a decreasing trend in aerosol loading after 2008, as suggested by a recent study (Zhang et al., 2017).

\section{Summary and conclusions}

Using Terra (2000-2015) and Aqua (2002-2015) Collection 6 (C6) MODIS DT, MISR (2000-2015) and CERES ES8/SSF data, both AOT and SWARE trends are estimated over global oceans. The results of this study are intercompared with analyses from several other studies that derived AOT trends using different instruments (e.g., active vs. passive) over different observing scenes (e.g., cloudy vs. cloud-free). This study suggests the following:

1. Updating the analysis from Zhang and Reid (2010), which examined the AOT trend over global oceans using the Collection 5 (C5) Terra MODIS DT aerosol data for 2000-2009, the use of the newly released C6 Terra MODIS DT aerosol products introduces a marginal difference in derived global and regional AOT trends.

2. Using the near-full data record from Terra (20002015), Aqua (2002-2015) and MISR (2000-2015), global and regional AOT trends are derived using overocean C6 MODIS DT and MISR data. A negligible AOT trend $\left(0.0003\right.$ AOT decade $\left.{ }^{-1}\right)$ is found using Aqua C6 MODIS DT data, but a higher AOT trend of 0.008 AOT decade ${ }^{-1}$ is found using Terra C6 MODIS DT data, while a slight negative trend is derived using MISR data $\left(-0.005\right.$ AOT decade $\left.{ }^{-1}\right)$. It is suspected that the difference may be introduced by calibration-related issues for one or all sensors, such as the recently reported cross-talk in thermal channels for Terra MODIS (Moeller and Frey, 2016) and a slight decrease in signal sensitivity for Terra MISR (Limbacher and Kahn, 2017). After accounting for potential calibration drifts, negligible AOT trends are found over global oceans using data from all sensors.

3. Regionally, statistically significant increases in aerosol loading over time are found over regions such as the Indian Bay of Bengal, the Arabian Sea and the Red Sea. Statistically significant negative AOT trends are also found over the eastern US coast and the Mediterranean Sea. This is in agreement with all three sensors (MODIS Aqua, MODIS Terra and MISR).

4. Using collocated MODIS and CERES data over global oceans, the cloud-free SW flux (SWARE) trends are also estimated for the near-full Terra (2000-2015) and 
Aqua (2002-2015) data records. After accounting for the potential calibration/ADM/near-surface wind related issues, small negative (positive) trends of -0.5 to $-0.6 \mathrm{~W} \mathrm{~m}^{-2} \mathrm{decade}^{-1} \quad\left(0.5-0.6 \mathrm{~W} \mathrm{~m}^{-2} \mathrm{decade}^{-1}\right)$ are found for Terra-based analysis and a near-zero trend is found for using Aqua data, and the results are fairly consistent regardless of whether CERES SSF or ES-8 SW fluxes are used. Regionally, positive SW flux trends are found over regions such as the Bay of Bengal and the Arabian Sea, whereas statistically significant negative trends are found over the eastern US coast and the Mediterranean Sea. The signs of the regional SW flux trends are in good agreement with what has been found for AOT trends.

5. Very high correlations are found between MODIS DT AOT and CERES cloud-free SW flux values using $2 \times$ $2^{\circ}$ (latitude/longitude) gridded multiyear mean Terra (2000-2015) and Aqua (2002-2015) data. The SW aerosol direct forcing efficiency is estimated to be $-60 \mathrm{~W} \mathrm{~m}^{-2} \mathrm{AOT}^{-1}$ and a SWARE value of $-7 \mathrm{~W} \mathrm{~m}^{-2}$ is derived over global oceans. The results are consistent, regardless of whether Terra or Aqua data or CERES ES8 or SSF data are used. Regionally, over the southwest coast of Africa, where smoke aerosol particles dominate in summer months, a SW aerosol direct forcing efficiency value of $\sim-40 \mathrm{~W} \mathrm{~m}^{-2} \mathrm{AOT}^{-1}$ is found, again, regardless of the datasets used. SW aerosol direct forcing efficiency values of -50 to $-80 \mathrm{~W} \mathrm{~m}^{-2} \mathrm{AOT}^{-1}$ are also found for the Arabian Sea, the northwest coast of Africa, coastal China and the Indian Bay of Bengal, where dust and pollutant aerosols dominate. It is also worth noting that a nonlinear relationship is found between SWARE and AOT.

6. Factors that could impact SWARE trend analysis include cloud contamination, calibration drifts, ADMs, ocean wind patterns and OTC clouds. The largest sources of uncertainty in the derived SWARE trends are found to be related to ADMs/surface wind speeds, while cloud contamination has a minor impact on the estimated SWARE trends.

7. Finally, trend analyses from this study are intercompared with results from several selected studies (e.g., Zhang and Reid, 2010; Alfaro-Contreras et al., 2016; Toth et al., 2016). Consistency in increasing/decreasing AOT trends is found among the studies, using passiveand active-based instruments, over cloud-free and cloudy skies, as well as using narrowband and broadband observations over regions such as the Bay of Bengal, the Arabian Sea, the eastern US coast and the Mediterranean Sea. Note that the abovementioned studies are derived with different instruments that have different sampling methods with different uncertainties under different observing conditions. The fact that consis- tencies are found in those studies, adds fidelity to some of the studies that are difficult to evaluate otherwise.

Data availability. All data used in this study are publically available, and the details of the datasets are mentioned in Sect. 2. The MODIS data are downloaded from the NASA Level-1 and Atmosphere Archive \& Distribution System (https://ladsweb.modaps. eosdis.nasa.gov/; accessed on 17 October 2017). The MISR, CERES and CALIOP data are obtained from the NASA Langley Atmospheric Science Data Center (https://eosweb.larc.nasa.gov/; accessed on 17 October 2017).

Competing interests. The authors declare that they have no conflict of interest.

Acknowledgements. Author Ricardo Alfaro-Contreras acknowledges the support from a NASA project NNX14AJ13G and an NSF project IIA-1355466. Author Jianglong Zhang also acknowledges the support from an ONR 32 project N00014-16-1-2040 (grant 11843919). Author Jeffrey S. Reid was supported by ONR 32 project N00014-16-1-2040.

Edited by: Armin Sorooshian

Reviewed by: two anonymous referees

\section{References}

Alfaro-Contreras, R., Zhang, J., Campbell, J. R., and Reid, J. S.: Investigating the frequency and interannual variability in global above-cloud aerosol characteristics with CALIOP and OMI, Atmos. Chem. Phys., 16, 47-69, https://doi.org/10.5194/acp-16-472016, 2016.

Al Senafi, F. and Anis, A.: Shamals and climate variability in the Northern Arabian/Persian Gulf from 1973-2012, Int. J. Climatol., 35, 4509-4528, https://doi.org/10.1002/joc.4302, 2015.

Barkstrom, B. R. and Wielicki, B. A.: Cloud and the Earth's Radiant Energy System (CERES) Algorithm and Theoretical Basis Document: CERES Data Processing Objectives and Architecture (Subsystem 0), 1996.

Chin, M., Diehl, T., Tan, Q., Prospero, J. M., Kahn, R. A., Remer, L. A., Yu, H., Sayer, A. M., Bian, H., Geogdzhayev, I. V., Holben, B. N., Howell, S. G., Huebert, B. J., Hsu, N. C., Kim, D., Kucsera, T. L., Levy, R. C., Mishchenko, M. I., Pan, X., Quinn, P. K., Schuster, G. L., Streets, D. G., Strode, S. A., Torres, O., and Zhao, X.-P.: Multi-decadal aerosol variations from 1980 to 2009: a perspective from observations and a global model, Atmos. Chem. Phys., 14, 3657-3690, https://doi.org/10.5194/acp14-3657-2014, 2014.

Christopher, S. A.: Satellite remote sensing methods for estimating clear Sky shortwave Top of atmosphere fluxes used for aerosol studies over the global oceans, Remote Sens. Environ., 115, 3002-3006, https://doi.org/10.1016/j.rse.2011.06.003, 2011.

Christopher, S. A. and Zhang, J.: Daytime variation of shortwave direct radiative forcing of biomass burning aerosols from GOES 8 imager, J. Atmos. Sci., 59, 681-691, 2002a. 
Christopher, S. A. and Zhang, J.: Shortwave aerosol radiative forcing from MODIS and CERES observations over the oceans, Geophys. Res. Lett., 29, 1859, https://doi.org/10.1029/2002GL014803, 2002b.

Christopher, S. A. and Jones, T. A.: Short-wave aerosol radiative efficiency over the global oceans derived from satellite data, Tellus B, 60, 636-640, https://doi.org/10.1111/j.16000889.2008.00353.x, 2008.

Diner, D. J., Beckert, J., Reilly, T., Bruegge, C., Conel, J., Kahn, R., Martonchik, J., Ackerman, T., Davies, R., Gerstl, S., Gordon, H., Muller, J.-P., Myneni, R., Sellers, P., Pinty, B., and Verstraete, M.: Multi-angle Imaging SpectroRadiometer (MISR) instrument description and experiment overview, IEEE T. Geosci. Remote Sens., 36, 1072-1087, https://doi.org/10.1109/36.700992, 1998.

Feng, Q., Hsu, N. C., Yang, P., and Tsay, S.-C.: Effect of thin cirrus cloud on dust optical depth retrievals from MODIS observations, IEEE T. Geosci. Remote, 49, 2819-2827, https://doi.org/10.1109/TGRS.2011.2118762, 2011

Huang, J., Hsu, N. C., Tsay, S. C., Jeong, M.-Y., Holben, B. N., Berkoff, T. A., and Ellsworth, J. W.: Susceptibility of aerosol optical thickness retrievals to thin cirrus contamination during the BASE-ASIA campaign, J. Geophys. Res., 116, D08214, https://doi.org/10.1029/2010JD014910, 2011.

Hsu, N. C., Gautam, R., Sayer, A. M., Bettenhausen, C., Li, C., Jeong, M. J., Tsay, S.-C., and Holben, B. N.: Global and regional trends of aerosol optical depth over land and ocean using SeaWiFS measurements from 1997 to 2010, Atmos. Chem. Phys., 12, 8037-8053, https://doi.org/10.5194/acp-12-8037-2012, 2012.

IPCC: Climate Change 2013: The Physical Science Basis: Summary for Policymakers, Cambridge, UK, 2013.

Kaufman, Y. J., Remer, L. A., Tanre, D., Li, R.-R., Kleidman, R., Mattoo, S., Levy, R., Eck, T., Holben, B. N., Ichoku, C., Martins, V., and Koren, I.: A critical examination of the residual cloud contamination and diurnal sampling effects on MODIS estimates of aerosol over ocean, IEEE T. Geosci. Remote, 43, 2886-2897, 2005.

Kahn, R. A., Gaitley, B. J., Garay, M. J., Diner, D. J., Eck, T., Smirnov, A., and Holben, B. N.: Multiangle Imaging Spectroradiometer global aerosol product assessment by comparison with Aerosol Robotic Network, J. Geophys. Res., 115, D23209, https://doi.org/10.1029/2010JD014601, 2010.

Kato, S., Rose, F. G., Sun-Mack, S., Walter, F. M., Chen, Y., Rutan, D. A., Stephens, G. L., Loeb, N. G., Minnis, P., Wielicki, B. A., Winker, D. M., Charlock, T. P., Stackhouse, P. W., Xu, K.-M., and Collins, W. D.: Improvements of top-of-atmosphere and surface irradiance computations with CALIPSO-, CloudSat-, and MODIS-derived cloud and aerosol properties, J. Geophys. Res., 116, D19209, https://doi.org/10.1029/2011JD016050, 2011.

Kendall, M. G.: Rank Correlation Methods, Griffin, London, 1975. Klingmüller, K., Pozzer, A., Metzger, S., Stenchikov, G. L., and Lelieveld, J.: Aerosol optical depth trend over the Middle East, Atmos. Chem. Phys., 16, 5063-5073, https://doi.org/10.5194/acp-16-5063-2016, 2016.

Levy, R. C., Mattoo, S., Munchak, L. A., Remer, L. A., Sayer, A. M., Patadia, F., and Hsu, N. C.: The Collection 6 MODIS aerosol products over land and ocean, Atmos. Meas. Tech., 6, 29893034, https://doi.org/10.5194/amt-6-2989-2013, 2013.
Li, J., Carlson, B. E., Dubovik, O., and Lacis, A. A.: Recent trends in aerosol optical properties derived from AERONET measurements, Atmos. Chem. Phys., 14, 1227112289, https://doi.org/10.5194/acp-14-12271-2014, 2014.

Limbacher, J. A. and Kahn, R. A.: Updated MISR dark water research aerosol retrieval algorithm - Part 1: Coupled $1.1 \mathrm{~km}$ ocean surface chlorophyll $a$ retrievals with empirical calibration corrections, Atmos. Meas. Tech., 10, 1539-1555, https://doi.org/10.5194/amt-10-1539-2017, 2017.

Loeb, N. G. and Kato, S.: $T$ op-of-atmosphere direct radiative effect of aerosols from the Clouds and the Earth's Radiant Energy System (CERES) satellite instrument, J. Climate, 15, 1474-1484, 2002.

Loeb, N. G., Smith, N. M., Kato, S., Miller, W. F., Gupta, S. K., Minnis, P., and Wielicki, B. A.: Angular distribution models for top-of-atmosphere radiative flux estimation from the Clouds and the Earth's Radiant Energy System instrument on the Tropical Rainfall Measuring Mission Satellite, Part I: Methodology, J. Appl. Meteorol., 42, 240-266, 2003.

Mann, H. B.: Nonparametric tests against trend, Econometrica, 13, 245-259, 1945.

Mishchenko, M. I., Liu, L., Geogdzhayev, I. V., Li, J., Carlson, B. E., Lacis, A. A., Cairns, B., and Travis, L. D.: Aerosol retrievals from channel-1 and -2 AVHRR radiances: long-term trends updated and revisited, J. Quant. Spectrosc. Ra., 113, 1974-1980, 2012.

Moeller, C. and Frey, R.: Impact of Terra/MODIS PV LWIR cross talk on L1 and L2 Products, The MODIS Science Team Meeting, Silver Spring, MD, 6-10 June 2016, 2016.

Penner, J. E., Charlson, R. J., Schwartz, S. E., Hales, J. M., Laulainen, N. S., Travis, L., Leifer, R., Novakov, T., Ogren, J., and Radke, L. F.: Quantifying and minimizing uncertainty of climate forcing by anthropogenic aerosols, B. Am. Meteorol. Soc., 75, 375-400, 1994.

Remer, L. A., Kaufman, Y. J., Tanré D., Mattoo, S., Chu, D. A., Martins, J. V., Li, R. R., Ichoku, C., Levy, R. C., Kleidman, R. G., Eck, T. F., Vermote, E., and Holben, B. N.: The MODIS aerosol algorithm, products, and validation, J. Atmos. Sci., 62, 947-973, https://doi.org/10.1175/JAS3385.1, 2005.

Remer, L. A., Kaufman, Y. J., and Kleidman, R. G.: Comparison of three years of Terra and Aqua MODIS aerosol optical thickness over the Global Oceans, IEEE Geosci. Remote S., 3, 537-540, 2006.

Shi, Y., Zhang, J., Reid, J. S., Holben, B., Hyer, E. J., and Curtis, C.: An analysis of the collection 5 MODIS over-ocean aerosol optical depth product for its implication in aerosol assimilation, Atmos. Chem. Phys., 11, 557-565, https://doi.org/10.5194/acp11-557-2011, 2011.

Solmon, F., Nair, V. S., and Mallet, M.: Increasing Arabian dust activity and the Indian summer monsoon, Atmos. Chem. Phys., 15, 8051-8064, https://doi.org/10.5194/acp-15-8051-2015, 2015.

Suttles, J. T., Green, R. N., Minnis, P., and Stowe, L. L: Angular radiation models for Earth-atmosphere system, I - Shortwave radiation, Rep. NASA RP-1184, NASA, Greenbelt, Md., 144 pp., 1988.

Thomas, G. E., Poulsen, C. A., Siddans, R., Sayer, A. M., Carboni, E., Marsh, S. H., Dean, S. M., Grainger, R. G., and Lawrence, B. N.: Validation of the GRAPE single view aerosol retrieval for ATSR-2 and insights into the long term global 
AOD trend over the ocean, Atmos. Chem. Phys., 10, 4849-4866, https://doi.org/10.5194/acp-10-4849-2010, 2010.

Tomé, A. R. and Miranda, P. M. A.: Piecewise linear fitting and trend changing points of climate parameters, Geophys. Res. Lett., 31, L02207, https://doi.org/10.1029/2003GL019100, 2004.

Toth, T. D., Zhang, J., Campbell, J. R., Reid, J. S., Shi. Y, Johnson, R. S., Smirnov, A., Vaughan, M. A., and Winker, D. M.: Investigating enhanced Aqua MODIS aerosol optical depth retrievals over the mid-to-high latitude Southern Oceans through intercomparison with co-located CALIOP, MAN, and AERONET data set, J. Geophys. Res.-Atmos., 118, 4700-4714, https://doi.org/10.1002/jgrd.50311, 2013.

Toth, T. D., Zhang, J., Campbell, J. R., Reid, J. S., and Vaughan, M. A.: Temporal variability of aerosol optical thickness vertical distribution observed from CALIOP, J. Geophys. Res.-Atmos., 121, 9117-9139, https://doi.org/10.1002/2015JD024668, 2016.

Weatherhead, E. C., Reinsel, G. C., Tiao, G. C., Meng, X. L., Choi, D., Cheang, W. K., Keller, T., DeLuisi, J., Wuebbles, D. J., Kerr, J. B., Miller, A. J., Oltmans, S. J., and Frederick, J. E.: Factors affecting the detection of trends: statistical considerations and applications to environmental data, J. Geophys. Res., 103, 17149-17161, 1998.

Wielicki, B. A., Barkstrom, B. R., Harrison, E. F., Lee III, R. B., Smith, G. L., and Cooper, J. E.: Clouds and the Earth's Radiant Energy System (CERES): an Earth observing system experiment, B. Am. Meteorol. Soc., 77, 853-868, 1996.

Winker, D. M. and coauthors.: The CALIPSO mission: a global 3-D view of aerosols and clouds, B. Am. Meteorol. Soc., 91, 12111229, 2010.

Zhang, J. and Christopher, S. A.: Longwave radiative forcing of Saharan dust aerosols from Terra, Geophys. Res. Lett., 30, 2188, https://doi.org/10.1029/2003GL018479, 2003.
Zhang, J. and Reid, J. S.: MODIS aerosol product analysis for data assimilation: assessment of level 2 aerosol optical thickness retrievals, J. Geophys. Res., 111, D22207, https://doi.org/10.1029/2005JD006898, 2006.

Zhang, J. and Reid, J. S.: An analysis of clear sky and contextual biases using an operational over ocean MODIS aerosol product, Geophys. Res. Lett., 36, L15824, https://doi.org/10.1029/2009GL038723, 2009.

Zhang, J. and Reid, J. S.: A decadal regional and global trend analysis of the aerosol optical depth using a data-assimilation grade over-water MODIS and Level 2 MISR aerosol products, Atmos. Chem. Phys., 10, 10949-10963, https://doi.org/10.5194/acp-1010949-2010, 2010.

Zhang, J., Christopher, S. A., Remer, L. A., and Kaufman, Y. J.: Shortwave aerosol radiative forcing over cloud-free oceans from Terra: 1. Angular models for aerosols, J. Geophys. Res., 110, D10S23, https://doi.org/10.1029/2004JD005008, 2005a.

Zhang, J., Christopher, S. A., Remer, L. A., and Kaufman, Y. J.: Shortwave aerosol radiative forcing over cloud-free oceans from Terra: 2. Seasonal and global distributions, J. Geophys. Res., 110, D10S24, https://doi.org/10.1029/2004JD005009, 2005b.

Zhang, J., Reid, J. S., Alfaro-Contreras, R., and Xian, P.: Has China been exporting less air pollution over the past decade?, Geophys. Res. Lett., 44, 2941-2948, https://doi.org/10.1002/2017GL072617, 2017.

Zhao, X.-P., Chan, P. K., and Heidinger, A. K.: A global survey of the effect of cloud contamination on the aerosol optical thickness and its long-term trend derived from operational AVHRR satellite observations, J. Geophys. Res., 118, 28492857, https://doi.org/10.1002/jgrd.50278, 2013. 